Mack, Leoni; Andersen, Hans Estrup; Beklioğlu, Meryem; Bucak, Tuba; Couture, Raoul-Marie; Cremona, Fabien; Ferreira, M. Teresa; Hutchins, Michael G.; Mischke, Ute; Molina-Navarro, Eugenio; Rankinen, Katri; Venohr, Markus; Birk, Sebastien. 2019. The future depends on what we do today - projecting Europe's surface water quality into three different future scenarios.

(C) 2019 Elsevier B.V.

This manuscript version is made available under the CC-BY-NC-ND 4.0 license http://creativecommons.org/licenses/by-nc-nd/4.0/ (cc) EY-NC-ND

This version available http://nora.nerc.ac.uk/522340/

NERC has developed NORA to enable users to access research outputs wholly or partially funded by NERC. Copyright and other rights for material on this site are retained by the rights owners. Users should read the terms and conditions of use of this material at http://nora.nerc.ac.uk/policies.html\#access

NOTICE: this is an unedited manuscript accepted for publication. The manuscript will undergo copyediting, typesetting, and review of the resulting proof before publication in its final form. During the production process errors may be discovered which could affect the content. A definitive version was subsequently published in Science of the Total Environment (2019), 668. 470484. https://doi.org/10.1016/i.scitotenv.2019.02.251

www.elsevier.com/ 


\section{The future depends on what we do today - Projecting Europe's surface water quality into three different future scenarios}

Running title: Different scenarios for surface water quality

Leoni Mack ${ }^{\mathrm{a}}$, Hans Estrup Andersen ${ }^{\mathrm{b}}$, Meryem Beklioğlu ${ }^{\mathrm{c}}$, Tuba Bucak ${ }^{\mathrm{c}}$, Raoul-Marie Couture $^{\mathrm{d}, \mathrm{k}}$, Fabien Cremona ${ }^{\mathrm{e}}$, M. Teresa Ferreira ${ }^{\mathrm{f}}$, Michael G. Hutchins ${ }^{\mathrm{g}}$, Ute Mischke ${ }^{\mathrm{h}}$, Eugenio Molina-Navarro ${ }^{\mathrm{b}}$, Katri Rankinen ${ }^{\mathrm{i}}$, Markus Venohr ${ }^{\mathrm{h}, \mathrm{l}}$, Sebastian Birk $^{\mathrm{a}, \mathrm{j}^{*}}$

${ }^{a}$ Department of Aquatic Ecology, Faculty of Biology, University of Duisburg-Essen, Germany

${ }^{\mathrm{b}}$ Department of Bioscience, Aarhus University, Silkeborg, Denmark

${ }^{\mathrm{c}}$ Limnology Laboratory, Department of Biological Sciences, Middle East Technical University, Ankara, Turkey

${ }^{\mathrm{d}}$ Norwegian Institute for Water Research, Oslo, Norway

${ }^{\mathrm{e}}$ Chair of Hydrobiology and Fishery, Institute of Agricultural and Environmental Sciences, Estonian University of Life Sciences, Tartu, Estonia

${ }^{\mathrm{f}}$ Centro de Estudos Florestais, Universidade Técnica de Lisboa, Instituto Superior de Agronomia, Tapada da Ajuda, Lisboa, Portugal

${ }^{\mathrm{g}}$ Centre for Ecology and Hydrology, Wallingford, UK

${ }^{\mathrm{h}}$ Leibniz-Institute of Freshwater Ecology and Inland Fisheries, Department of Shallow Lakes and Lowland Rivers, Berlin, Germany

${ }^{\mathrm{i}}$ Finnish Environment Institute, Helsinki, Finland

${ }^{\mathrm{j}}$ Centre for Water and Environmental Research, University of Duisburg-Essen, Germany

${ }^{\mathrm{k}}$ Department of Chemistry, Laval University, Québec, Canada

${ }^{1}$ Geography Department, Humboldt-University of Berlin, Germany 
*Corresponding author: Sebastian Birk, Department of Aquatic Ecology, Faculty of Biology, Universitätsstrasse 5, 45141 Essen, Germany.

Email: sebastian.birk@uni-due.de

\section{Abstract}

There are infinite possible future scenarios reflecting the impacts of anthropogenic multiple stress on our planet. These impacts include changes in climate and land cover, to which aquatic ecosystems are especially vulnerable. To assess plausible developments of the future state of European surface waters, we considered two climate scenarios and three storylines describing land use, management and anthropogenic development ('Consensus', 'Techno' and 'Fragmented', which in terms of environmental protection represent best-, intermediate- and worst-case, respectively). Three lake and four river basins were selected, representing a spectrum of European conditions through a range of different human impacts and climatic, geographical and biological characteristics. Using process-based and empirical models, freshwater total nitrogen, total phosphorus and chlorophyll-a concentrations were projected for 2030 and 2060. Under current conditions, the water bodies mostly fail good ecological status. In future predictions for the Techno and Fragmented World, concentrations further increased, while concentrations generally declined for the Consensus World. Furthermore, impacts were more severe for rivers than for lakes. Main pressures identified were nutrient inputs from agriculture, land use change, inadequately managed water abstractions and climate change effects. While the basins in the Continental and Atlantic regions were primarily affected by land use changes, in the Mediterranean/Anatolian the main driver was climate change. The Boreal basins showed combined impacts of land use and climate change and clearly reflected the climate-induced future trend of agricultural activities shifting northward. The storylines showed positive effects on ecological status by classical mitigation 
measures in the Consensus World (e.g. riparian shading), technical improvements in the Techno World (e.g. increasing wastewater treatment efficiency) and agricultural extensification in the Fragmented World. Results emphasize the need for implementing targeted measures to reduce anthropogenic impacts and the importance of having differing levels of ambition for improving the future status of water bodies depending on the societal future to be expected.

Key words: Storylines, multiple stressors, climate change, land use change, water quality modelling, total nitrogen, total phosphorus, chlorophyll-a

\section{Introduction}

The surface waters worldwide are impacted by multiple anthropogenic stressors that threaten their ecosystem functioning, integrity and services (Jeppesen et al., 2014). Stressors can be seen as external abiotic or biotic factors derived from human intervention, moving a receptor (e.g. biological community, ecosystem state) out of its normal operating range (Sabater et al., 2019). The stressors affecting surface waters arise from a variety of sources: point source pollution encompasses urban wastewater effluents, stormwater overflows and industrial emissions, whereas diffuse source pollution mainly originates from agricultural practices, discharges without connection to the sewage network, forestry and urban run-off. The main hydromorphological pressures include physical alterations of the channel, bed or riparian area of the water bodies, as well as the disruption of connectivity by embankments, dams, barriers and locks. Furthermore, water abstraction is disturbing the functioning of surface waters (European Environment Agency, 2018). As a consequence, they are one of the most degraded ecosystem types in the world (WWF, 2016). 
Accelerated population growth and globalization are expected to further exacerbate drivers like agriculture and urbanization and subsequent pressures affecting surface waters in the decades to come (Ferreira et al., 2019; Sala et al., 2000). For instance, a higher food demand will result in an expansion of agriculture, displacing pasture or forest and subsequently reinforcing nutrient emissions and their impacts (Pacheco and Sanches Fernandes, 2016). The resulting eutrophication, which already constitutes a widespread environmental problem, will increase and lead to further deterioration in water quality and biodiversity (Valle Junior et al., 2015; Almeida et al., 2018; Hutchins et al., 2018). Excess phytoplankton growth can lead to harmful algal blooms, anoxia and mortality of aquatic flora and fauna, resulting in severe ecological and economic losses (Bucak et al., 2018; Carvalho et al., 2013). Increasing climate change is expected to intensify this deterioration due to changes in temperature and precipitation patterns, which will alter nutrient inputs to water bodies as well as their physicochemical properties and biological communities (Chapra et al., 2017; Jeppesen et al., 2014). Current trends in agriculture and forestry practices will also promote global climatic changes and alterations in river flow (Grafton et al., 2018; Jackson et al., 2005). These expected trends highlight the importance of adequate methods to predict the future extent of anthropogenic drivers and their ecological impacts so as to support appropriate actions for mitigation and adaptation.

Water quality models seek to comprehend the complex cause-effect chains of drivers acting on the state of water bodies. They are used to simulate the current status and predict future trends in water quality, and to project the effects of potential mitigation measures. The numerous available models differ in, inter alia, the stressors addressed, their spatio-temporal scale or the input data required (Tsakiris and Alexakis, 2012). Numerical water quality models employ process-based approaches that use mathematical functions to describe ecosystem processes, requiring ample understanding of the mechanisms underlying these 
processes. Recently, interdisciplinary model chains have been applied, often linking processbased models (PMs) with empirical models (EMs), and thereby enabling increasingly comprehensive projections of the water body state (Kiesel et al., 2018). EMs can be used to establish stressor-response relationships without recourse to mechanistical insights, including various regression and machine learning methods (Fernandes et al., 2018; Ferreira et al., 2017; Lindenschmidt, 2006). The coupling of interdisciplinary models to investigate water quality offers a powerful tool for environmental management, especially when dealing with the challenge of multiple-stressor mitigation (Segurado et al., 2018).

Multiple stressors stem from pressures on an ecosystem acting in concert, affecting these systems in not easily predictable ways (Côté et al., 2016). Multiple stressors become more prevalent due to the rising trends in population density and globalization, inducing intensified agricultural and urban land use, hydropower generation and climate change (Ormerod et al., 2010). To counteract these increasing threats on the aquatic ecosystems, environmental policies like the European Water Framework Directive (WFD; European Commission, 2000) have been implemented, stipulating actions towards sustainable river basin management.

The WFD was adopted as the core of the European Union water policy in 2000 to improve the quality and ecosystem integrity of surface waters and to promote sustainable water use. One major aim of the WFD is to achieve good ecological status (representing only slight deviations from the near-natural reference conditions) for all European surface and groundwaters (European Commission, 2000). Good ecological status, however, is currently not achieved in $59 \%$ of river and $48 \%$ of lake water bodies, mainly due to diffuse pollution and hydromorphological degradation (European Environment Agency, 2018). Given the high proportion of water bodies showing moderate or worse status, appropriate strategies to combat the effects of multiple stressors are required. 
In this study, we investigate seven European lake and river basin case studies that had modeled the combined effects of climate, land use and management change on the chemical and biological state of their water bodies (Ferreira et al., 2016). These cases had been undertaken using a common analytical framework stipulated in the European research project MARS (Managing Aquatic ecosystems and water Resources under multiple Stress; http://mars-project.eu/), which analyzed the relations between multiple stressors and the functions and services of water resources at river basin-scale (Hering et al., 2015). Here, we synthesize the outcomes of these seven individual modeling studies and provide a representative overview on the extent and direction of future developments of European surface waters. In particular, we compare the current water quality and its future trends against the environmental objectives set by the WFD. Using the three quality parameters total nitrogen (TN), total phosphorus (TP) and chlorophyll-a concentrations, two time-horizons are projected (2030 and 2060) under three different scenarios of change. These projections are related to harmonized environmental quality standards (EQS) for meeting good ecological status according to the WFD. We discuss the modeling outcomes in terms of their potential threats to the aquatic ecosystems and possible mitigation options.

\section{Materials and Methods}

\section{Case study descriptions}

We examined two lake and five river basins located in four different biogeographical regions of Europe (European Environment Agency, 2002; Figure 1). Lake Vansjø (Norway), the river Lepsämänjoki (Finland), as well as Lake Võrtsjärv (Estonia) are located in the Boreal region. The river Thames (United Kingdom) is located in the Atlantic region. The rivers Odense (Denmark) and Middle Elbe (Germany) are located in the Continental region. Lake Beyşehir (Turkey) is located on the border between the Mediterranean and the Inner Anatolian region. 
The main anthropogenic influences in all basins are agricultural land use, water abstraction and climate change, whereas in the Central European basins urban land cover is also important.

To assess the impacts of multiple stresses on the future chemical and biological water quality, nutrient and chlorophyll-a concentrations have been projected into the future using PMs and EMs. Some of these studies simulated solely nutrient or chlorophyll-a concentrations, depending on data availability and model practicability (Table 1). First, a conceptual stressorresponse framework for each case study was established by implementing the DPSIR scheme (i.e. Driver-Pressure-State-Impact-Response; Smeets and Weterings, 1999) to identify origins and consequences of the basin-specific environmental issues. In this context, 'Drivers' represent climate change or anthropogenic influences like land use change. The consequential 'Pressures' (e.g. enhanced nutrient input or water abstraction) affect the 'State' of the aquatic ecosystems under study (e.g. water quality and quantity). Its 'Impact' (e.g. altered ecological status or ecosystem services) may then induce a political or societal 'Response' (e.g. ecosystem mitigation; Birk, 2019; Hering et al., 2015). Then, the specific modeling strategy for each basin was developed based on these conceptual models, and the availability of empirical data and PMs. The majority of studies used a model chain of PMs for the future predictions. Two case studies used PM outputs as input variables for EMs to simulate chlorophyll-a concentrations. An overview of the models (including abbreviations and references) used for simulating nutrient and chlorophyll-a concentrations and their input variables is given in Table 1. A short description of each case study is provided below.

\section{Lepsämänjoki}

The river Lepsämänjoki is part of the Vantaanjoki river basin in the south of Finland. The whole area is forested to a large proportion and intensively used for outdoor recreation. The 
river serves as the secondary drinking water resource for the city of Helsinki and drains into the Gulf of Finland. About a quarter of the basin is used for agriculture and the resulting excess of nutrients causes problematic eutrophication in the water bodies. Thus, the ecological status of Lepsämänjoki and its tributary Härkälänjoki are moderate and poor, respectively. For the statistical analyses of this study, data of an expanded area with characteristics similar to the Lepsämänjoki were used.

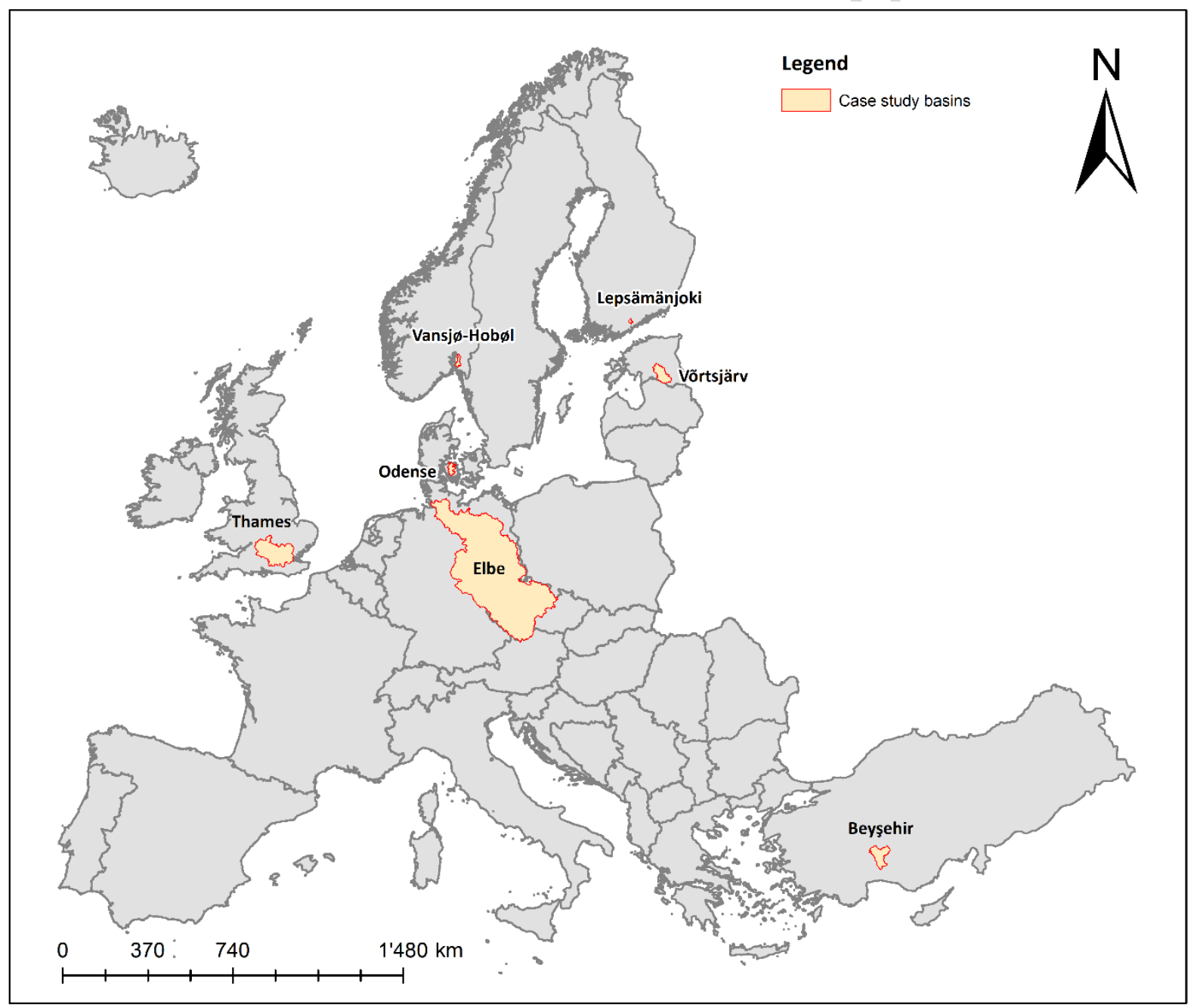

Figure 1: Location of the seven lake and river case study basins addressed in this study.

There are two discharge gauging stations in the Lepsämänjoki basin and five in the extended area, three meteorological stations for the measurement of temperature and precipitation, and one for solar radiation. For determining future nitrate nitrogen $\left(\mathrm{NO}_{3}-\mathrm{N}\right)$ and $\mathrm{TP}$ concentrations, 175 observations were collected for INCA-N and INCA-P, covering the period 
1985 to 2014 (Ferreira et al., 2016; Rankinen et al., 2019). For comparison with the other case studies, modeled $\mathrm{NO}_{3}-\mathrm{N}$ concentrations were converted into $\mathrm{TN}$ using the formula $\mathrm{TN}=1.195 * \mathrm{NO}_{3}-\mathrm{N}+0.526$ derived from empirical relationships, which proved to be valid for the river Lepsämänjoki. Chlorophyll-a concentrations were modeled using Generalized Linear Mixed Models (GLMM; Bolker et al., 2009) and Boosted Regression Trees (BRT; Elith et al., 2008) and the means of both models were used in this study.

\section{Lake Vansjф}

Lake Vansjø in the south-east of Norway is mainly fed by the river Hobøl and is divided into several subbasins. The largest ones are Storefjorden in the eastern and Vanemfjorden in the western part. The deeper Storefjorden serves as a drinking water resource and is draining into the shallower Vanemfjorden (mean depth of $3.8 \mathrm{~m}$ ) that further flows into the Oslo Fjord. The humic Vanemfjorden does not exhibit stable stratification and shows low transparency (Moe et al., 2016). The Vansjø-Hobøl basin is mainly forested and agriculture covers $15 \%$ of the area. Excessive amounts of phosphorus, mainly originating from agriculture, cause a long history of river eutrophication. Until 2007, cyanobacterial blooms occurred in Vanemfjorden, which have then been restricted by the implementation of agricultural measures (Couture et al., 2018; Skarbøvik and Bechmann, 2010). The data used in this study were collected from the most impacted subbasin Vanemfjorden which currently has moderate ecological status.

Daily flow was monitored at the gauging station at Høgfoss from 1983 until 2013. Three meteorological stations, located between the main basins, collected daily data on precipitation, temperature and wind. In the period 1996 to 2004, suspended solid and TP samples were taken weekly or biweekly as part of a monitoring program. Water column sampling has been performed weekly or biweekly since 1976, providing data on phosphorus, nitrogen and chlorophyll-a. Phosphorus loadings from wastewater treatment plant (WWTP) effluents and scattered dwellings were also considered. Biweekly data for chlorophyll-a for 
May to October were also obtained from the monitoring program, covering the period 1990 to 2012. Future TP and chlorophyll-a concentrations were modeled by Couture et al. (2018), using the models INCA-P and MyLake, respectively.

\section{Lake Võrtsjärv}

Lake Võrtsjärv is the largest lake within Estonia, located in the central-southern part of the country. Due to its shallow character (mean depth of $2.8 \mathrm{~m}$ ) and its large wind-exposed surface area, it is highly turbid, polymictic, and characterized by vertically homogenous nutrient, oxygen and temperature profiles across the lake zones (Cremona et al., 2018). For around 135 days per year, the lake is ice covered. As it is located in an area of flat relief the water outflow is restricted and the lake exhibits strong seasonal water level fluctuations with a maximal amplitude of $3.2 \mathrm{~m}$ during the snow melt (Cremona et al., 2018; Nõges et al., 2018). About half of the water in Lake Võrtsjärv comes from the river Väike-Emajõgi, which still possesses its natural flow regime (Cremona et al., 2017). The main land use in the basin is agriculture, therefore extensive nutrient inputs since 1961 facilitate high phytoplankton biomass, to which cyanobacteria contribute $60 \%$ to $95 \%$ (Cremona et al., 2018; Nõges et al., 2018).

Data for modeling were collected on a monthly basis from 2005 to 2014, except meteorological data that were available at daily resolution. Precipitation data were obtained by averaging two time-series from Valga and Tõlliste stations. River flow of Väike Emajõgi, temperature and dissolved inorganic carbon fluxes were used for $B R T$ modeling to obtain future chlorophyll-a concentrations of Lake Võrtsjärv (Cremona et al., 2017).

\section{Odense}

The Odense basin is located on the island of Funen in Denmark and includes the Odense River, draining into the Odense Fjord and further into the Baltic Sea. The ecological integrity 
of the area has been impaired by urbanization, agriculture, channelization, summer droughts and groundwater abstraction (Molina-Navarro et al., 2018). Due to excessive nutrient inputs by agriculture, the Odense Fjord experienced hypoxia, algal blooms and the disappearance of seabed vegetation and fauna in the past (Conley et al., 2007). Furthermore, subsurface tile drainage in about half of the basin causes significant hydrological changes (Thodsen et al., 2015).

Data for daily flow and biweekly nutrient loads (organic nitrogen and phosphorus, nitrate and phosphate) were obtained from four monitoring stations in the Odense basin, whereby one station measured nutrient loads every second day. The catchment model for the Odense was set up by Thodsen et al. (2015) and updated by Molina-Navarro et al. (2018). Future TN and TP concentrations were based on results from SWAT model applications (Molina-Navarro et al.,2018).

\section{Thames}

The Thames is the second longest river in the UK, located in the south of England. The main land uses in its rural upper part are intensive agriculture and pasture for grazing. The lower basin further east is highly populated, including major urban centers such as London. The Thames serves as a drinking water resource for about 14 million people and is strongly impacted by anthropogenic activities. WWTPs cause increased nutrient levels and locks for navigation prolong the residence time of the water. In addition, flow in the river is slowed down through its connection to canal systems, enhancing its vulnerability to phytoplankton blooms (Bussi et al., 2016). Study investigations comprised three geographically-distinct aspects: a reach of the Thames at Eynsham (basin area of approx. $1600 \mathrm{~km}^{2}$ ) representing the 'Upper Thames', a reach at Wallingford (basin area of approx. $3500 \mathrm{~km}^{2}$ ) representing the 'Middle Thames' and the Farmoor Reservoir, which is an important drinking water supply for the city of Swindon. 
Hutchins et al. (2018) simulated TN, TP and chlorophyll-a concentrations for Upper and Middle Thames, as well as chlorophyll-a for the Farmoor Reservoir. A dense network of gauging stations measures hydro-climatic, chemical and biotic data in the basin. Daily precipitation and potential evapotranspiration were observed since 1961 on a $1 \mathrm{~km}$ grid. Flow data were collected by 19 monitoring stations on a daily basis, while the groundwater levels were measured in variable intervals. Since 2009, there are 21 gauging sites installed across the water body, six of them within the main channel, recording water temperature, nitrate, TP and chlorophyll-a concentrations in a weekly interval. Additionally, water temperature and dissolved oxygen concentration are recorded at four other monitoring stations at an hourly resolution. For Upper and Middle Thames, the QUESTOR model was used, while chlorophyll-a predictions for Farmoor Reservoir were obtained using PROTECH.

\section{Middle Elbe}

The basin of Middle Elbe covers a large part of the north-east of Germany and is located between the city of Schmilka and the dam Geesthacht. It drains almost $25 \%$ of the country and is strongly affected by channelization and water regulation, thus half of it is classified as 'heavily modified'. Water quality is mainly impaired by point source and diffuse agricultural pollution resulting in eutrophication. Low water availability, high amounts of nutrients and reduced shading trigger high phytoplankton biomasses, which are transported along the Elbe into the North Sea where the mineralization of detritus causes severe oxygen depletion, acting as a barrier for diadromous fish species (Mischke et al., 2016).

For the period 2005 to 2010, emissions, instream retention, loads and concentrations of TN and TP were modeled using the model MONERIS. A connected module, PhytoBasinRisk, was used to quantify chlorophyll-a concentrations. The models consider GIS-processed data e.g. on population, municipal WWTPs, land use, fertilizer surplus, slope, soil types and river topology and morphology, as well as monthly precipitation and evaporation, water quality and 
daily run-off data. The simulations for the seasonal means of TN, TP and chlorophyll-a were performed by Mischke et al. (2016).

\section{Lake Beyşehir}

Representing the largest freshwater lake in the water scarce Mediterranean basin, Lake Beyşehir is an important water resource for Turkey. The ecosystem of the lake, which is oligo- to mesotrophic, and of average depth of $5-6 \mathrm{~m}$, has been impaired primarily by excessive water abstractions, sewage effluents and the introduction of exotic fish species (Bucak et al., 2018). The lake is surrounded by two National Parks (Beyşehir and Kızıldağ) and features various natural protection sites of ecological relevance, providing habitat for important bird and plant species. Its north-eastern part is dominated by intensive crop farming, while the western part features forested mountains with small areas of low-intensive agriculture. Water availability of Lake Beyşehir is threatened by unmanaged water abstractions, already requiring water transfers from a nearby basin into the lake (Bucak et al., 2017). As is commonplace in most Mediterranean areas, the low water availability in the basin makes the system vulnerable to further water cutbacks, which are expected in the future (Levi et al., 2016).

Physico-chemical and biological variables of the lake and its main inflows were collected monthly from April 2010 until March 2012. Daily meteorological data for precipitation, temperature, wind, solar radiation and relative humidity for the stations Beyşehir and Seydişehir were available for the period 1960 to 2012. The $S W A T$ model for the hydrological balance was used to simulate evapotranspiration, infiltration, percolation, runoff and nutrient loads, for Lake Beyşehir (Bucak et al., 2017). For the setup of the two lake models PCLake and GLM, daily meteorological and physico-chemical data were required. Since field data were collected monthly, they were linearly interpolated to generate daily data (Bucak et al., 
2018). These data and modelling resources underpinned prediction of future TN, TP and chlorophyll-a concentrations (Bucak et al., 2018). 
Table 1: Basin characteristics and model overview for the case studies. PM: Process-based model, EM: Empirical model, TN: Total nitrogen, TP: Total phosphorus, Chl-a: Chlorophyll-a.

\begin{tabular}{|c|c|c|c|c|c|c|c|c|c|c|c|c|c|c|}
\hline \multirow[b]{2}{*}{ Case study } & \multicolumn{2}{|c|}{$\begin{array}{c}\begin{array}{c}\text { River/Lake } \\
\text { characteristics }\end{array} \\
\end{array}$} & \multicolumn{5}{|c|}{ Basin characteristics } & \multirow[b]{2}{*}{$\begin{array}{c}\text { Main land } \\
\text { uses }\end{array}$} & \multirow[b]{2}{*}{ Main stressors } & \multicolumn{3}{|c|}{ Modeling } & \multirow[b]{2}{*}{$\begin{array}{c}\text { Climate } \\
\text { model used }\end{array}$} & \multirow[b]{2}{*}{ References } \\
\hline & $\begin{array}{c}\text { Water } \\
\text { category }\end{array}$ & $\begin{array}{l}\text { Surface } \\
\text { area/ } \\
\text { Length }\end{array}$ & Altitude & $\begin{array}{c}\text { Size } \\
{\left[\mathbf{k m}^{2}\right]}\end{array}$ & $\begin{array}{l}\text { Biogeo- } \\
\text { graphical } \\
\text { region }\end{array}$ & $\begin{array}{c}\text { Mean } \\
\text { annual } \\
\text { temper- } \\
\text { ature } \\
{\left[{ }^{\circ} \mathrm{C}\right]} \\
\end{array}$ & $\begin{array}{c}\text { Mean } \\
\text { annual } \\
\text { precipi- } \\
\text { tation } \\
{[\mathrm{mm} / \mathrm{yr}]}\end{array}$ & & & Model & Input & Output & & \\
\hline \multirow[t]{2}{*}{ Lepsämänjoki } & \multirow[t]{2}{*}{ River } & \multirow[t]{2}{*}{$33.5 \mathrm{~km}$} & \multirow[t]{2}{*}{ Lowland } & \multirow[t]{2}{*}{214} & \multirow[t]{2}{*}{ Boreal } & \multirow[t]{2}{*}{4} & \multirow[t]{2}{*}{650} & \multirow{2}{*}{$\begin{array}{l}\text { Mainly } \\
\text { forest; } 23 \% \\
\text { arable land }\end{array}$} & \multirow{2}{*}{$\begin{array}{c}\text { Diffuse } \\
\text { pollution; } \\
\text { hydrological } \\
\text { alteration }\end{array}$} & $\begin{array}{l}\text { PMs: } \\
\text { INCA-N; } \\
\text { INCA-P } \\
\end{array}$ & $\begin{array}{c}\text { Meteorological data; } \\
\text { information on land use; } \\
\text { soil moisture deficit and } \\
\text { hydrologically effective } \\
\text { rainfall }\end{array}$ & TN; TP & \multirow{2}{*}{$\begin{array}{l}\text { 2030: } \\
\text { GFDL; } \\
\text { 2060: IPSL }\end{array}$} & \multirow{2}{*}{$\begin{array}{l}\text { Rankinen et } \\
\text { al., } 2019\end{array}$} \\
\hline & & & & & & & & & & $\begin{array}{l}\text { EMs: } \\
\text { GLMM; } \\
\text { BRT }\end{array}$ & $\begin{array}{l}\text { Water temperature, TP, } \\
\text { nitrate, soluble reactive } \\
\text { phosphorus, } 7 \text {-day } \\
\text { minimum runoff }\end{array}$ & Chl-a & & \\
\hline \multirow[t]{2}{*}{ Lake Vansjø } & \multirow[t]{2}{*}{ Lake } & \multirow[t]{2}{*}{$36 \mathrm{~km}^{2}$} & \multirow[t]{2}{*}{ Lowland } & \multirow[t]{2}{*}{675} & & \multirow[t]{2}{*}{5.6} & \multirow[t]{2}{*}{829} & \multirow{2}{*}{$\begin{array}{l}78 \% \text { forest; } \\
15 \% \\
\text { agriculture }\end{array}$} & \multirow{2}{*}{$\begin{array}{l}\text { Diffuse } \\
\text { pollution; } \\
\text { hydrological } \\
\text { and physical } \\
\text { alteration }\end{array}$} & $\begin{array}{c}\text { PM: } \\
\text { INCA-P }\end{array}$ & $\begin{array}{l}\text { Meteorological data; } \\
\text { runoff, hydrologically } \\
\text { effective rainfall, soil } \\
\text { moisture deficit }\end{array}$ & TP & \multirow[t]{2}{*}{ GFDL; IPSL } & \multirow[t]{2}{*}{$\begin{array}{c}\text { Couture et } \\
\text { al., } 2018\end{array}$} \\
\hline & & & & & & & & & & $\begin{array}{c}\text { PM: } \\
\text { MyLake }\end{array}$ & $\begin{array}{l}\text { Meteorological data; } \\
\text { inflow and phosphorus } \\
\text { fluxes }\end{array}$ & Chl-a & & \\
\hline $\begin{array}{c}\text { Lake } \\
\text { Voortsjärv* }\end{array}$ & Lake & $270 \mathrm{~km}^{2}$ & Lowland & 270 & Boreal & 4.5 & 650 & \begin{tabular}{|}
$40 \%$ \\
agriculture; \\
$27 \%$ \\
agricultural \\
drained land; \\
$24 \%$ forest
\end{tabular} & $\begin{array}{l}\text { Diffuse } \\
\text { pollution; } \\
\text { hydrological } \\
\text { alteration }\end{array}$ & EM: BRT & $\begin{array}{l}\text { Dissolved inorganic } \\
\text { carbon; temperature; } \\
\text { river flow }\end{array}$ & Chl-a & GFDL; IPSL & $\begin{array}{c}\text { Cremona et } \\
\text { al., } 2017\end{array}$ \\
\hline
\end{tabular}




\begin{tabular}{|c|c|c|c|c|c|c|c|c|c|c|c|c|c|c|}
\hline \multirow[b]{2}{*}{ Case study } & \multicolumn{2}{|c|}{$\begin{array}{c}\text { River/Lake } \\
\text { characteristics }\end{array}$} & \multicolumn{5}{|c|}{ Basin characteristics } & \multirow[b]{2}{*}{$\begin{array}{c}\text { Main land } \\
\text { uses }\end{array}$} & \multirow[b]{2}{*}{ Main stressors } & \multicolumn{3}{|c|}{ Modeling } & \multirow[b]{2}{*}{$\begin{array}{c}\text { Climate } \\
\text { model used }\end{array}$} & \multirow[b]{2}{*}{ References } \\
\hline & $\begin{array}{c}\text { Water } \\
\text { category }\end{array}$ & $\begin{array}{c}\text { Surface } \\
\text { area/ } \\
\text { Length }\end{array}$ & Altitude & $\mid \begin{array}{c}\text { Size } \\
{\left[\mathbf{k m}^{2}\right]}\end{array}$ & $\begin{array}{l}\text { Biogeo- } \\
\text { graphical } \\
\text { region }\end{array}$ & $\begin{array}{c}\text { Mean } \\
\text { annual } \\
\text { temper- } \\
\text { ature } \\
{\left[{ }^{\circ} \mathrm{C}\right]} \\
\end{array}$ & $\begin{array}{c}\text { Mean } \\
\text { annual } \\
\text { precipi- } \\
\text { tation } \\
{[\mathrm{mm} / \mathrm{yr}]}\end{array}$ & & & Model & Input & Output & & \\
\hline Odense & River & $60 \mathrm{~km}$ & Lowland & 1,061 & Continental & 8.7 & 812 & $\begin{array}{c}68 \% \\
\text { agriculture; } \\
16 \% \text { urban; } \\
10 \% \text { forest }\end{array}$ & $\begin{array}{c}\text { Diffuse } \\
\text { pollution; } \\
\text { hydrological } \\
\text { and physical } \\
\text { alteration; } \\
\text { climate change }\end{array}$ & PM: SWAT & $\begin{array}{c}\text { Meteorological data; } \\
\text { information on land use; } \\
\text { agricultural } \\
\text { management; slope; soil } \\
\text { type }\end{array}$ & $\mathrm{TN} ; \mathrm{TP}$ & IPSL & $\begin{array}{l}\text { Molina- } \\
\text { Navarro et } \\
\text { al., } 2018\end{array}$ \\
\hline Thames & River & $354 \mathrm{~km}$ & $\begin{array}{l}\text { Up- to } \\
\text { lowland }\end{array}$ & 9,948 & Atlantic & 11 & & $\begin{array}{l}45 \% \text { arable } \\
\text { land; } 34 \% \\
\text { grassland; } \\
11 \% \text { forest }\end{array}$ & $\begin{array}{l}\text { Diffuse and } \\
\text { point source } \\
\text { pollution; } \\
\text { hydrological } \\
\text { and physical } \\
\text { alteration; } \\
\text { climate change; } \\
\text { water } \\
\text { abstraction }\end{array}$ & $\begin{array}{c}\text { PM: } \\
\text { QUESTOR } \\
\text { (River } \\
\text { Thames) } \\
\\
\text { PM: } \\
\text { PROTECH } \\
\text { (Farmoor } \\
\text { Reservoir) }\end{array}$ & $\begin{array}{c}\text { Meteorological data; } \\
\text { daily flow; water } \\
\text { temperature; } \\
\text { concentrations of } \\
\text { pollutants } \\
\\
\text { Meteorological data; } \\
\text { river nutrient data; in- } \\
\text { and outflow; discharge }\end{array}$ & \begin{tabular}{|c} 
TN; TP; \\
Chl-a
\end{tabular} & GFDL; IPSL & $\begin{array}{c}\text { Hutchins et } \\
\text { al., } 2018\end{array}$ \\
\hline Middle Elbe & River & $585 \mathrm{~km}$ & Lowland & 83,920 & Continental & 10.9 & 742 & $\begin{array}{c}56 \% \text { arable } \\
\text { land; } 30 \% \\
\text { forest }\end{array}$ & \begin{tabular}{|} 
Diffuse and \\
point source \\
pollution; \\
hydrological \\
and physical \\
alteration; \\
climate change
\end{tabular} & \begin{tabular}{|c} 
\\
PM: \\
PhytoBasin \\
Risk
\end{tabular} & $\begin{array}{c}\text { Meteorological data; } \\
\text { discharge; data on } \\
\text { population; land use; } \\
\text { wastewater effluents; } \\
\text { slope; soil type; river } \\
\text { morphology }\end{array}$ & TN; TP & GFDL; IPSL & $\begin{array}{c}\text { Mischke et } \\
\text { al., } 2016\end{array}$ \\
\hline
\end{tabular}




\begin{tabular}{|c|c|c|c|c|c|c|c|c|c|c|c|c|c|c|}
\hline \multirow[b]{2}{*}{ Case study } & \multicolumn{2}{|c|}{$\begin{array}{c}\text { River/Lake } \\
\text { characteristics }\end{array}$} & \multicolumn{5}{|c|}{ Basin characteristics } & \multirow[b]{2}{*}{$\begin{array}{c}\text { Main land } \\
\text { uses }\end{array}$} & \multirow[b]{2}{*}{ Main stressors } & \multicolumn{3}{|c|}{ Modeling } & \multirow[b]{2}{*}{$\begin{array}{c}\text { Climate } \\
\text { model used }\end{array}$} & \multirow[b]{2}{*}{ References } \\
\hline & $\begin{array}{c}\text { Water } \\
\text { category }\end{array}$ & $\begin{array}{c}\text { Surface } \\
\text { area/ } \\
\text { Length }\end{array}$ & Altitude & $\begin{array}{c}\text { Size } \\
{\left[\mathrm{km}^{2}\right]}\end{array}$ & $\begin{array}{l}\text { Biogeo- } \\
\text { graphical } \\
\text { region }\end{array}$ & $\begin{array}{c}\text { Mean } \\
\text { annual } \\
\text { temper- } \\
\text { ature }\left[{ }^{\circ} \mathrm{C}\right]\end{array}$ & $\begin{array}{c}\text { Mean } \\
\text { annual } \\
\text { precipi- } \\
\text { tation } \\
{[\mathrm{mm} / \mathrm{yr}]}\end{array}$ & & & Model & Input & Output & & \\
\hline Lake Beyşehir & Lake & $650 \mathrm{~km}^{2}$ & Upland & 4,704 & $\begin{array}{c}\text { Mediterranean } \\
\text { /Anatolian }\end{array}$ & 11 & 490 & $\begin{array}{c}43 \% \\
\text { shrubland; } \\
26 \% \\
\text { agriculture; } \\
11 \% \text { forest }\end{array}$ & \begin{tabular}{|c|} 
Water \\
abstraction; \\
diffuse \\
pollution; \\
climate change
\end{tabular} & $\begin{array}{l}\text { PMs: GLM; } \\
\text { PCLake }\end{array}$ & $\begin{array}{l}\text { Meteorological data; } \\
\text { hydrological and } \\
\text { chemical loads; } \\
\text { biological data }\end{array}$ & $\begin{array}{c}\text { TN; TP; } \\
\text { Chl-a }\end{array}$ & GFDL; IPSL & $\begin{array}{c}\text { Bucak et al., } \\
2018\end{array}$ \\
\hline
\end{tabular}

PMs: GLM - General Lake Model (Hipsey et al., 2017), PCLake (Janse, 2005), MONERIS - Modeling Of Nutrient Emissions in RIver Systems (Venohr et al., 2011), PhytoBasinRisk (Mischke et al., 2018), SWAT - Soil and Water Assessment Tool model (Arnold et al., 1998), QUESTOR - QUality Evaluation and Simulation TOol for River systems (Boorman, 2003; Hutchins et al., 2016), PROTECH - Phytoplankton RespOnses To Environmental CHange (Reynolds et al., 2001), INCA - Integrated Nitrogen model for multiple source assessment in CAtchments (Whitehead et al., 1998), MyLake (Couture et al., 2015; Saloranta and Andersen, 2007); EMs: BRT - Boosted Regression Trees model (Elith et al., 2008), GLMM - Generalized Linear Mixed Models (Bolker et al., 2009);

Meteorological data: precipitation, air and water temperature, global radiation, air pressure, cloud cover, relative humidity, wind speed; Biological data: Initial values of phytoplankton biomass/composition and zooplankton biomass from the first day of simulation; GFDL/IPSL: Global Climate Models used for the modeling.

*For the modeling only the basin characteristics of Väike-Emajögi tributary were used; its main land uses are: $51 \%$ forest, $46 \%$ agriculture. 


\section{Future scenarios and storylines}

For the future climate simulations, the two Global Climate Models GFDL-ESM2M (GFDL; Dunne et al., 2012) and IPSL-CM5A-LR (IPSL; Dufresne et al., 2013) were applied, differing in their spatial resolution and state variables. IPSL is projecting at an atmospheric grid of $2.5^{\circ} \times 3.75^{\circ}$, using wind, pressure, temperature and cloud cover. GFDL has a grid of $2.5^{\circ} \times 2.0^{\circ}$ and additionally provides cloud ice, cloud fraction and humidity as outputs (Couture et al., 2018).

The climate models were driven by two Representative Concentration Pathways (RCPs). These are defined by their rise in radiative forcing levels from 1850 to 2100 due to anthropogenic greenhouse gas emissions (van Vuuren et al., 2011). The pathway representing a moderate mitigation of greenhouse gas concentrations is RCP 4.5, which stabilizes around 2080 at the $4.5 \mathrm{~W} / \mathrm{m}^{2}$ level (Thomson 2011). In RCP 8.5, the radiative forcing rises throughout the century (and further on), reaching a value of $8.5 \mathrm{~W} / \mathrm{m}^{2}$ in 2100 . These different scenarios, including combinations of GFDL or IPSL with RCP 4.5 or 8.5 , result in varying global temperature and precipitation projections. For the modeling period 2025 to 2034 (referred to as time-horizon '2030' in the following), an average increase of up to $22 \%$ in precipitation and up to $2.5^{\circ} \mathrm{C}$ in temperature was forecasted, showing significant differences between the European regions. For 2055 to 2064 ('2060'), precipitation change varied between a $30 \%$ decrease and $30 \%$ increase, and temperature increased by $0.6-4.3{ }^{\circ} \mathrm{C}$. The changes in climate variables specific to each case study are listed in Table 2.

The RCPs were combined with different Shared Socioeconomic Pathways (SSPs), specifying alternative futures of societal development (O'Neill et al., 2017). They differ in the extent to which future challenges are taken up to mitigate environmental damage and to adapt to climate change. The main factors for mitigation include technological advance, the role of 
international policy organizations and determinants of energy and land use. Critical influences on the challenges to adaptation are future inequality, poverty and achievement (or failure) to attain different development objectives. In our study, we referred to SSP2 and SSP3 representing moderate and high mitigation and adaptation challenges, respectively, and to SSP5 with high mitigation and low adaptation challenges. In this context, SSP5 represents a future in which, despite weak climate policies and carbon-based energy, improved human capital produces stronger instruction and better adaption strategies to climate change.

Table 2: Absolute change in temperature $\left[{ }^{\circ} \mathrm{C}\right]$ and percentage change in precipitation [mm/year], simulated for the 2030 and 2060 time-horizons against the baseline period and downscaled for the specific case studies. GFDL (GFDL-ESM2M) and IPSL (IPSL-CM5A-LR) are Global Climate Models used to simulate large-scale future climate simulations, driven by RCP (Representative Concentration Pathway) 4.5 and RCP 8.5, which represent the anthropogenic emission of greenhouse gases.

\begin{tabular}{|c|c|c|c|c|c|c|c|c|c|}
\hline \multirow{3}{*}{ Case study } & \multirow{3}{*}{ Baseline } & \multicolumn{4}{|c|}{ RCP 4.5} & \multicolumn{4}{|c|}{ RCP 8.5} \\
\hline & & \multicolumn{2}{|c|}{2030} & \multicolumn{2}{|c|}{2060} & \multicolumn{2}{|c|}{2030} & \multicolumn{2}{|c|}{2060} \\
\hline & & GFDI & IPSL & GFDL & IPSL & GFDL & IPSL & GFDL & IPSL \\
\hline \multicolumn{10}{|c|}{ Temperature increase $\left[{ }^{\circ} \mathbf{C}\right]$} \\
\hline Lepsämänjoki & $1981-2010$ & 1.4 & - & - & 2.5 & 1.4 & - & - & 2.5 \\
\hline Lake Vansjø & $1983-2014$ & 0.5 & 2.1 & 0.7 & 2.5 & 0.6 & 2.5 & 1.0 & 3.2 \\
\hline Lake Võrtsjärv & $2005-2014$ & 1.5 & 0.0 & 1.2 & 2.6 & 0.6 & 1.6 & 1.9 & 4.3 \\
\hline Odense & $2011-2020$ & - & 0.8 & - & 1.6 & - & 1.0 & - & 2.7 \\
\hline Thames & 1960-1999 & 0.6 & 0.6 & 1.1 & 1.2 & 0.5 & 0.8 & 1.4 & 2.2 \\
\hline Middle Elbe & $1971-2001$ & 1.2 & 1.5 & 1.6 & 0.9 & 0.8 & 2.5 & 1.6 & 3.9 \\
\hline Lake Beyşehir & $2006-2015$ & 0.0 & 0.6 & 0.6 & 1.7 & 0.7 & 1.3 & 2.0 & 3.4 \\
\hline \multicolumn{10}{|c|}{ Precipitation change [\%] } \\
\hline Lepsämänjoki & $1981-2010$ & 1 & - & - & 8 & 3 & - & - & 11 \\
\hline Lake Vansjø & 1983-2014 & 5 & 7 & 3 & 8 & 6 & 9 & 5 & 11 \\
\hline Lake Võrtsjärv & 2005-2014 & 16 & -2 & 8 & 13 & 5 & 1 & 30 & 29 \\
\hline Odense & $2011-2020$ & - & 1 & - & 2 & - & 6 & - & 13 \\
\hline Thames & 1960-1999 & 0 & 0 & -8 & -1 & -2 & 11 & -4 & 10 \\
\hline Middle Elbe & 1971-2001 & 3 & 5 & 7 & 8 & 5 & 8 & 7 & 8 \\
\hline Lake Beyşehir & 2006-2015 & 22 & 1 & 9 & -17 & 0 & 2 & -16 & -30 \\
\hline
\end{tabular}

On the basis of the combined climate and socioeconomic scenarios, three different storylines at European level have been defined to describe economic, environmental, political and climatic trends in the future (Sanchez et al., 2015): 


\section{Consensus World}

The Consensus World is based on SSP2 and RCP 4.5. It connects the objectives for economic growth with a sustainable and effective resource use. Economic and population growth continue as they are currently, and energy is saved in order to reduce emissions using a mix of fossil fuel and renewable sources. The existing awareness and interest in nature conservation is based on strong regulations by the European Union. After 2020, the current guidelines and policies are enhanced in a more integrated way. To meet these regulations, cheap water management strategies with mid- to long-term sustainability are implemented. Also, there is a trend towards green infrastructure, utilizing the benefits of natural processes and structures.

\section{Techno World}

The Techno World storyline is based on SSP5 and RCP 8.5. In this storyline, economic growth is the main objective, and the European Union supports innovative technologies and capital increasing solutions. The high energy demand is met by the excessive use of fossil fuels, causing rising $\mathrm{CO}_{2}$ emissions. Alternative energy sources are also utilized, though without any environmental consideration. The environmental policies stagnate due to the focus on trade and economic growth, thus any interventions which seek to protect or improve the environment are mainly initiated by individuals or communes. Locally, provisioning and cultural services are prioritized, while nature-based regulating services are neglected. Water management uses technical solutions to minimize risks to human health and capital and to meet current needs, though sustainability is disregarded.

\section{Fragmented World}

The Fragmented World storyline is based on SSP3 and RCP 8.5. A large economic gap within Europe is emerging, caused by the absence of international trade. In principle, Southern Europe is suffering from a decreasing economy, while the rest will experience a growth. On 
account of the loss of international consensus, a lack of resources will arise, especially in currently economically weak countries. To meet the extended energy demand, increased use of fossil fuels and renewable energies takes place. Natural preservation is only considered in rich countries on a local scale. The current environmental policies are stopped around 2025 and the focus is set on economic development. Water management strategies do not extend beyond short term actions for meeting the water and food demand of the current generation. Furthermore, flood protection is implemented in regions with a high economic value.

\section{Downscaling of storylines}

The specific implications of each storyline for individual basins was evaluated by the scientist responsible for each case study, involving local stakeholders and water managers, and considering climate and land use changes (Table 3). Simulated climate data for each region were obtained from the 'Inter-Sectoral Impact Model Intercomparison Project' (www.isimip.org), providing daily meteorological data on a $0.5^{\circ}$ x $0.5^{\circ}$ grid. For the implementation of land use change, the redistribution of land use areas, including agricultural and urban regions, was estimated per storyline. Furthermore, future rates of fertilizer application, water abstraction and WWTP effluents were considered. Regarding water management, erosion control and the implementation of riparian buffer zones were taken into account. However, not all specific mitigation measures for scenario implementation were described in the case studies.

The Consensus World represented the most environmentally friendly scenario, therefore the conditions implemented principally supported the best-case regarding water pollution. Agricultural and urban land cover, nutrient input by fertilization or WWTPs and water abstraction was generally smallest for the Consensus World. The Techno World represented intermediate stressor conditions, whereas the Fragmented World was associated with the 
worst-case scenario. It should be noted that, in contrast to Couture et al. (2018), the Fragmented World scenario of Lake Vansjø is treated as the worst-case and the Techno World is treated as the intermediate scenario.

\section{Model performances}

The performance of individual PMs was evaluated using the coefficient of determination $\left(\mathrm{R}^{2}\right)$ and percent bias (PBIAS) of the model validations. For phosphorus compounds (organic and inorganic phosphorus), validation measures with $\mathrm{R}^{2} \leq 0.40$ were considered as not satisfactory, $0.40<\mathrm{R}^{2} \leq 0.65$ as satisfactory, $0.65<\mathrm{R}^{2} \leq 0.80$ as good and $\mathrm{R}^{2} \geq 0.80$ as very good in their accuracy, whereas for nitrogen compounds (nitrate, ammonium, organic nitrogen, TN) and chlorophyll-a, $\mathrm{R}^{2} \leq 0.30$ were considered as not satisfactory, $0.30<\mathrm{R}^{2} \leq$ 0.60 as satisfactory, $0.60<\mathrm{R}^{2} \leq 0.70$ as good and $\mathrm{R}^{2} \geq 0.70$ as very good in their accuracy. Regarding PBIAS, we used absolute values. Validation measures with PBIAS $\geq|30|$ were considered as not satisfactory, $|20| \leq$ PBIAS $<|30|$ as satisfactory, $|15| \leq$ PBIAS $<|20|$ as good and PBIAS $<|15|$ as very good in their accuracy (Moriasi et al., 2015).

For the EMs, the explained deviances provided information about the accuracy of the models. The non-linear models of $B R T$ explaining $<30 \%$ of their deviance were considered as not satisfactory in their accuracy, $30-50 \%$ as satisfactory, $50-60 \%$ as good and $\geq 60 \%$ as very good. For the linear model $G L M M,<20 \%$ of explained deviance was considered as not satisfactory, $20-40 \%$ as satisfactory, $40-50 \%$ as good and $\geq 50 \%$ as very good.

\section{Processing of model simulations}

In our study, baseline (representing the current conditions) and future predictions of TN, TP and chlorophyll-a concentrations were summarized and compared between the case studies. Therefore, we calculated the mean concentrations for the GFDL and IPSL scenario results. 
Baseline and future concentrations were related to ecosystem type-specific nutrient and chlorophyll-a thresholds supporting the achievement of good ecological status according to the WFD (Beklioğlu et al., 2014; Couture et al., 2018; Mischke et al., 2011; Phillips et al., 2018; Poikane, 2009; Stefanidis et al., 2018; UK Technical Advisory Group, 2013). These thresholds allowed the model results to be set in the context of harmonized EQS. 
Table 3: Downscaling of storylines for the different case studies. The downscaling is focused on agricultural, urban and water-related development. WWTPs: Wastewater treatment plants, N: Nitrogen, P: Phosphorus.

\begin{tabular}{|c|c|c|c|c|c|c|c|c|}
\hline \multirow{2}{*}{ Storyline } & \multirow{2}{*}{ Category } & \multicolumn{7}{|c|}{ Case study } \\
\hline & & Lepsämänjoki & Lake Vansjø & Lake Võrtsjärv & Odense & Thames & Middle Elbe & Lake Beyşehir \\
\hline \multirow[t]{2}{*}{$\begin{array}{l}\text { Consensus } \\
\text { World }\end{array}$} & $\begin{array}{l}\text { Agricultural } \\
\text { and urban } \\
\text { development }\end{array}$ & $\begin{array}{l}50 \% \text { increase in } \\
\text { agricultural land } \\
\text { (deforestation); } \\
30 \% \text { increase in yields; } \\
\text { no change in } \\
\text { fertilization; } \\
\text { enhanced erosion } \\
\text { control; } \\
\text { crop rotation: } 40 \% \\
\text { spring cereals / - 30\% } \\
\text { winter cereals; } 15 \% \\
\text { grass; } 15 \% \text { fallow }\end{array}$ & $\begin{array}{l}10 \% \text { of grassland } \\
\text { turned into forest; } \\
30 \% \text { shift from } \\
\text { vegetables and crops to } \\
\text { unfertilized grasslands; } \\
50 \% \text { decrease in } \\
\text { fertilization; } \\
50 \% \text { decrease in } \\
\text { erosion; growing } \\
\text { season extended by } \\
\text { two months }\end{array}$ & \begin{tabular}{|l|}
$12 \%$ decrease in \\
forest; \\
$11 \%$ increase in \\
agricultural area; \\
$50 \%$ increase in \\
urban area
\end{tabular} & $\begin{array}{l}34 \% \text { decrease in arable } \\
\text { land; } \\
696 \% \text { increase in } \\
\text { grassland; } \\
125 \% \text { increase in forest; } \\
\text { around } 4 \% \text { decrease in } \\
\text { fertilization (depending on } \\
\text { farm type) }\end{array}$ & $\begin{array}{l}10 \% \text { decrease in } \\
\text { forest; } 20 \% \text { decrease } \\
\text { in grassland; } \\
20 \% \text { increase in urban } \\
\text { area; } \\
100 \% \text { increase in } \\
\text { shading }\end{array}$ & $\begin{array}{l}19 \% \text { decrease in arable } \\
\text { land; } \\
50 \% \text { increase in riparian } \\
\text { buffer zones; } \\
4 \% \text { decrease in population } \\
\text { size; } \\
20 \% \text { decrease in N loads; } \\
25 \% \text { decrease in P } \\
\text { accumulation in soils; } \\
23 \% \text { decrease in degree of } \\
\text { P saturation in soils }\end{array}$ & $\begin{array}{l}5 \% \text { of forest areas } \\
\text { turned into shrubland; } \\
20 \% \text { decrease in } \\
\text { fertilization }\end{array}$ \\
\hline & $\begin{array}{l}\text { Water- } \\
\text { related } \\
\text { development }\end{array}$ & $\begin{array}{l}\text { No change } \\
\text { implemented }\end{array}$ & $\begin{array}{l}50 \% \text { decrease in } \\
\text { effluents from } \\
\text { scattered dwellings and } \\
\text { WWTPs }\end{array}$ & \begin{tabular}{|l|} 
Water \\
abstraction \\
amounts to $10 \%$ \\
of mean annual \\
flow
\end{tabular} & Not considered ${ }^{\mathrm{b}}$ & $\begin{array}{l}20 \% \text { decrease in water } \\
\text { levels; } \\
4 \% \text { decrease in } \\
\text { urbanization }{ }^{\mathrm{c}} ; \\
10 \% \text { decrease in } \\
\text { grazers } ; 10 \% \\
\text { decrease in } \mathrm{TP}^{\mathrm{e}}\end{array}$ & $\begin{array}{l}31 \% \text { decrease in person } \\
\text { specific phosphorus } \\
\text { disposal }^{\mathrm{a}} \text {; } \\
\text { WWTP effluents contain } \\
23 \mathrm{mg} / \mathrm{L} \mathrm{N} \text { and } 1.8 \mathrm{mg} / \mathrm{L} \mathrm{P}\end{array}$ & $\begin{array}{l}10 \% \text { decrease in water } \\
\text { abstraction }\end{array}$ \\
\hline $\begin{array}{l}\text { Techno } \\
\text { World }\end{array}$ & \begin{tabular}{|l|} 
Agricultural \\
and urban \\
development
\end{tabular} & $\begin{array}{l}\text { Forest turned into } \\
\text { arable land; } \\
20 \% \text { increase in yields; } \\
20 \% \text { increase in } \\
\text { fertilization; } \\
\text { crop rotation: } 50 \% \\
\text { spring cereals / - 50\% } \\
\text { winter cereals; } 1.5 \% \text { of } \\
\text { forest turned into urban } \\
\text { areas }\end{array}$ & $\begin{array}{l}5 \% \text { of forest turned } \\
\text { into grassland; } \\
30 \% \text { of grassland } \\
\text { turned into arable land; } \\
15 \% \text { increase in } \\
\text { fertilization; } \\
15 \% \text { increase in } \\
\text { erosion; } \\
\text { growing season } \\
\text { extended by two } \\
\text { months }\end{array}$ & $\begin{array}{l}31 \% \text { decrease in } \\
\text { forest; } \\
30 \% \text { increase in } \\
\text { agricultural area; } \\
100 \% \text { increase in } \\
\text { urban area }\end{array}$ & $\begin{array}{l}20 \% \text { decrease in arable } \\
\text { land (with conversion to } \\
\text { willow); } 141 \% \text { increase in } \\
\text { grassland; } \\
\text { around } 4 \% \text { decrease in } \\
\text { fertilization (depending on } \\
\text { farm type) }\end{array}$ & $\begin{array}{l}10 \% \text { decrease in } \\
\text { arable land/forest; } \\
15 \% \text { decrease in } \\
\text { grassland; } \\
50 \% \text { increase in urban } \\
\text { area; } \\
25 \% \text { decrease in } \\
\text { shading }\end{array}$ & $\begin{array}{l}19 \% \text { decrease in arable } \\
\text { land; } \\
30 \% \text { decrease in riparian } \\
\text { buffer zones; } \\
12 \% \text { increase in } \\
\text { population size; } \\
8 \% \text { decrease in N loads; } \\
15 \% \text { decrease in P } \\
\text { accumulation in soils; } \\
13 \% \text { decrease in degree of } \\
\text { P saturation in soils }\end{array}$ & $\begin{array}{l}20 \% \text { of forest and } 10 \% \\
\text { of grassland turned into } \\
\text { arable land; } \\
10 \% \text { increase in } \\
\text { fertilization }\end{array}$ \\
\hline
\end{tabular}




\begin{tabular}{|c|c|c|c|c|c|c|c|c|}
\hline \multirow{2}{*}{ Storyline } & \multirow{2}{*}{ Category } & \multicolumn{7}{|c|}{ Case study } \\
\hline & & Lepsämänjoki & Lake Vansjø & Lake Võrtsjärv & Odense & Thames & Middle Elbe & Lake Beyşehir \\
\hline $\begin{array}{l}\text { Techno } \\
\text { World }\end{array}$ & $\begin{array}{l}\text { Water- } \\
\text { related } \\
\text { development }\end{array}$ & $\begin{array}{l}50 \% \text { decrease in } \\
\text { sewage due to } \\
\text { improved treatment }\end{array}$ & $\begin{array}{l}25 \% \text { increase in } \\
\text { effluents from } \\
\text { scattered dwellings }\end{array}$ & $\begin{array}{l}\text { Water } \\
\text { abstraction } \\
\text { amounts to } 15 \% \\
\text { of mean annual } \\
\text { flow }\end{array}$ & Not considered ${ }^{\mathrm{b}}$ & $\begin{array}{l}10 \% \text { decrease in water } \\
\text { levels; } \\
35 \% \text { increase in } \\
\text { urbanization } \text {; } \\
50 \% \text { decrease in } \\
\text { grazers }^{\mathrm{d}} ; 50 \% \text { increase } \\
\text { in } \mathrm{TP}^{\mathrm{e}}\end{array}$ & $\begin{array}{l}\text { 8\% decrease in person } \\
\text { specific phosphorus } \\
\text { disposal }{ }^{\mathrm{a}} ; \\
\text { WWTP effluents contain } \\
48 \mathrm{mg} / \mathrm{L} \text { N and 3mg/L P }\end{array}$ & $\begin{array}{l}10 \% \text { increase in water } \\
\text { abstraction }\end{array}$ \\
\hline \multirow[t]{2}{*}{$\begin{array}{l}\text { Fragmented } \\
\text { World }\end{array}$} & $\begin{array}{l}\text { Agricultural } \\
\text { and urban } \\
\text { development }\end{array}$ & $\begin{array}{l}\text { Up to } 90 \% \text { of forest } \\
\text { turned into arable land; } \\
25 \% \text { increase in yields; } \\
30 \% \text { increase in } \\
\text { fertilization; } \\
\text { mainly barley } \\
\text { monoculture; } \\
5 \% \text { of forest turned } \\
\text { into urban areas } \\
\end{array}$ & $\begin{array}{l}10 \% \text { of forest areas } \\
\text { turned into grassland; } \\
60 \% \text { of grassland } \\
\text { turned into arable land; } \\
30 \% \text { increase in } \\
\text { fertilization; } \\
30 \% \text { increase in } \\
\text { erosion; } \\
\text { growing season } \\
\text { extended by two } \\
\text { months }\end{array}$ & $\begin{array}{l}51 \% \text { decrease in } \\
\text { forest; } \\
52 \% \text { increase in } \\
\text { agricultural area; } \\
150 \% \text { increase in } \\
\text { urban area }\end{array}$ & $\begin{array}{l}10 \% \text { increase in arable } \\
\text { land; } \\
1 \% \text { decrease in grassland; } \\
80 \% \text { decrease in forest; } \\
\text { up to } 134 \% \text { increase in } \\
\text { fertilization (depending on } \\
\text { farm type) }\end{array}$ & \begin{tabular}{|l|}
$30 \%$ decrease in \\
arable land; \\
$20 \%$ increase in \\
forest; $45 \%$ increase \\
in grassland; 50\% \\
increase in urban area; \\
$100 \%$ decrease in \\
shading
\end{tabular} & $\begin{array}{l}19 \% \text { decrease in arable } \\
\text { land; } \\
80 \% \text { decrease in riparian } \\
\text { buffer zones; } \\
16 \% \text { decrease in } \\
\text { population size; } \\
26 \% \text { increase in N loads; } \\
13 \% \text { increase in P } \\
\text { accumulation in soils; } \\
4 \% \text { increase in degree of P } \\
\text { saturation in soils } \\
\end{array}$ & $\begin{array}{l}30 \% \text { arable land and } \\
\text { forest turned into } \\
\text { shrubland; } \\
30 \% \text { increase in } \\
\text { fertilization }\end{array}$ \\
\hline & $\left|\begin{array}{l}\text { Water- } \\
\text { related } \\
\text { development }\end{array}\right|$ & $\begin{array}{l}10 \% \text { increase in } \\
\text { effluents from } \\
\text { scattered dwellings }\end{array}$ & $\begin{array}{l}40 \% \text { increase in } \\
\text { effluents from } \\
\text { scattered dwellings and } \\
\text { WWTPs }\end{array}$ & $\begin{array}{l}\text { Water } \\
\text { abstraction } \\
\text { amounts to } 20 \% \\
\text { of mean annual } \\
\text { flow }\end{array}$ & Not considered ${ }^{\mathrm{b}}$ & $\begin{array}{l}25 \% \text { increase in water } \\
\text { levels; } \\
88 \% \text { increase in } \\
\text { urbanization } \\
50 \% \text { decrease in } \\
\text { grazers }{ }^{\mathrm{d}} ; 50 \% \text { increase } \\
\text { in } \mathrm{TP}^{\mathrm{e}}\end{array}$ & $\begin{array}{l}48 \% \text { increase in person } \\
\text { specific phosphorus } \\
\text { disposal }^{\mathrm{a}} \text {; } \\
\text { WWTP effluents contain } \\
75 \mathrm{mg} / \mathrm{L} \mathrm{N} \text { and } 6.5 \mathrm{mg} / \mathrm{L} \mathrm{P}\end{array}$ & $\begin{array}{l}30 \% \text { increase in water } \\
\text { abstraction }\end{array}$ \\
\hline
\end{tabular}

${ }^{a}$ An altered diet of city dwellers is predicted in terms of the quantity of meat consumption, altering phosphorus concentrations in feces.

${ }^{b}$ For the Odense basin only agricultural measures were considered; $68 \%$ of the area is used for agriculture.

${ }^{c}$ Urbanization affects the amounts of water abstractions and effluents.

${ }^{d}$ Invertebrate grazing changes as a response to altered pesticide loads in runoff.

${ }^{e} \mathrm{TP}$ concentration in tributaries and effluents. 


\section{Results}

After evaluating the model performances, we will depict the model simulations for nutrient and chlorophyll-a concentrations for the single case studies and their projections for timehorizons 2030 and 2060 and compare these to the ecosystem type-specific EQS.

\section{Measures of model accuracy}

The accuracy of modeled nitrogen-compounds showed a broad range, with Middle Thames and Middle Elbe performing best. Validation was not satisfactory for the PBIAS of Odense, as well as PBIAS and $\mathrm{R}^{2}$ of Lake Beyşehir. For phosphorus compounds, only Upper Thames and Middle Elbe revealed very good and satisfactory $\mathrm{R}^{2}$, respectively. PBIAS values, in contrast, ranged from satisfactory to very good for all case studies except Vansjø. Overall, chlorophyll-a simulations showed better model performances than TN and TP, especially when modeled by EMs, which showed good and very good accuracy. The PMs showed very good $\mathrm{R}^{2}$ for Vansjø, Lake Võrtsjärv and Farmoor Reservoir, whereas the PBIAS was very good for Vansjø, Middle Thames, Farmoor Reservoir and Lake Beyşehir (Table 4). In addition, the visual fits of modeled concentrations were considered satisfactory in all case studies.

\section{Model simulations for nutrients and chlorophyll-a}

For each of the different case studies the predicted future change in water quality relative to the ecosystem type-specific EQS is illustrated (Figure 2). Present day baseline and future values, as well as the EQS concentrations are listed in Table 5. For the majority of case studies, the concentrations of $\mathrm{TN}$ and $\mathrm{TP}$ were already exceeding the EQS at baseline conditions, whereas for chlorophyll-a, they were at good status. Regarding future predictions, exceedances from the EQS were highest for the Fragmented World, closely followed by the Techno World, whereas for the Consensus World the risk of failing good ecological status 
was least. Regarding the simulated indicators, chlorophyll-a concentrations showed the lowest excess of the EQS. For the Consensus storyline, four case studies showed chlorophyll-a concentrations meeting the threshold, compared to three for TP and one for TN. Furthermore, predictions in rivers revealed more pronounced changes in nutrient and chlorophyll-a concentrations in rivers than in lakes (Figure 2).

Table 4: Evaluation of model accuracies. Mean values of the model validation results for different stations and nitrogen/phosphorus-compounds are given.

\begin{tabular}{|c|c|c|c|c|c|}
\hline \multicolumn{6}{|c|}{ Process-based models } \\
\hline Variable & Water body & Model & \begin{tabular}{|c|} 
Temporal \\
scale
\end{tabular} & Mean $\mathbf{R}^{2}$ & Mean PBIAS \\
\hline \multirow{6}{*}{$\begin{array}{l}\text { Nitrogen- } \\
\text { compounds }\end{array}$} & Lepsämänjoki & INCA & Daily & 0.37 (satisfactory) & (very good) \\
\hline & Odense $^{\mathrm{a}}$ & SWAT & Daily & 0.44 (satisfactory) & (not satisfactory) \\
\hline & Upper Thames & QUESTOR & Daily & 0.35 (satisfactory) & (very good) \\
\hline & Middle Thames & QUESTOR & Daily & 0.77 (very good) & (very good) \\
\hline & Middle Elbe & MONERIS & Monthly & 0.97 (very good) & (very good) \\
\hline & Lake Beyşehir $^{b}$ & GLM, PCLake & \begin{tabular}{|l|} 
Daily \\
\end{tabular} & 0.15 (not satisfactory) & $>100 \quad$ (not satisfactory) \\
\hline \multirow{7}{*}{$\begin{array}{l}\text { Phosphorus- } \\
\text { compounds }\end{array}$} & Lepsämänjoki & INCA & Daily & 0.19 (not satisfactory) & 26.3 (satisfactory) \\
\hline & Lake Vansjø $\varnothing^{b}$ & MyLake & Daily & 0.32 (not satisfactory) & (not satisfactory) \\
\hline & Odense $^{\mathrm{a}}$ & SWAT & \begin{tabular}{|l|} 
Daily \\
\end{tabular} & 0.30 (not satisfactory) & (satisfactory) \\
\hline & Upper Thames & QUESTOR & Daily & 0.53 (satisfactory) & (very good) \\
\hline & Middle Thames & QUESTOR & Daily & 0.13 (not satisfactory) & (satisfactory) \\
\hline & Middle Elbe & MONERIS & Monthly & 0.92 (very good) & (very good) \\
\hline & Lake Beyşehir $^{\mathrm{b}}$ & GLM/PCLake & Daily & 0.16 (not satisfactory) & (good) \\
\hline \multirow{6}{*}{ Chlorophyll-a } & Lake Vansj $\varnothing^{\mathrm{b}}$ & MyLake & Daily & 0.44 (satisfactory) & (very good) \\
\hline & Upper Thames & QUESTOR & Daily & 0.57 (satisfactory) & (not satisfactory) \\
\hline & Middle Thames & QUESTOR & Daily & 0.22 (not satisfactory) & (very good) \\
\hline & Farmoor Reservoir & PROTECH & Weekly & 0.63 (very good) & (very good) \\
\hline & Middle Elbe & PhytoBasinRisk & Seasonal & 0.56 (satisfactory) & $($ good) \\
\hline & Lake Beyşehir $^{\mathrm{b}}$ & GLM/PCLake & Daily & 0.17 (not satisfactory) & (very good) \\
\hline \multicolumn{6}{|c|}{ Empirical models } \\
\hline Variable & Water body & Model & \begin{tabular}{|c|}
$\begin{array}{c}\text { Temporal } \\
\text { scale }\end{array}$ \\
\end{tabular} & \multicolumn{2}{|c|}{ Explained variance $(\%)$} \\
\hline \multirow{3}{*}{ Chlorophyll-a } & Lepsämänjoki & GLMM & Daily & 41 & (good) \\
\hline & Lepsämänjoki & BRT & Daily & 60 & (very good) \\
\hline & Lake Võrtsjärv & BRT & Monthly & 63 & (very good) \\
\hline
\end{tabular}

${ }^{a}$ Model accuracy calculations were based on the simulation of nutrient loads. Nutrient concentrations were calculated using loads and hydrological flows; flow statistics are described in Molina-Navarro et al. (2018).

${ }^{b}$ Model accuracy was obtained from the model calibration process.

\section{Total nitrogen}

The baseline and future TN simulations remained below the EQS only for Lake Beyşehir. The other case studies exceeded the thresholds at all times. This excess was particularly high for Odense (for Fragmented World), Upper and Middle Thames, which showed baseline and 
future concentrations three times higher than the threshold. Regarding the storylines, similar trends were simulated, except a high rise followed by a steep decline in Odense for the Fragmented World, which was not predicted for the Consensus and Techno World.

\section{Total phosphorus}

For baseline simulations, TP exceeded the EQS in all case studies except Lake Vansjø and Odense. For future predictions, Lake Vansjø and Odense still met the EQS for all scenarios, and Middle Elbe featured declining concentrations below the threshold for all storylines. All other case studies predicted future concentrations exceeding the EQS. As for TN, Upper and Middle Thames showed particularly high TP concentrations except for the Consensus World, where a strong reduction was simulated. The other case studies showed similar trends regarding the different storylines.

\section{Chlorophyll-a}

Upper Thames, Lake Vansjø and Lake Beyşehir showed baseline and future concentrations below the EQS for all scenarios. Lepsämänjoki and Middle Elbe met the EQS for baseline simulations and exhibited increasing concentrations for future simulations, leading to an excess of chlorophyll-a in all scenarios. Lake Võrtsjärv, Middle Thames and Farmoor Reservoir were exceeding the thresholds for baseline and future conditions, except Middle Thames for Consensus World. This excess was especially high in Farmoor Reservoir for all storylines, as well as in Middle Thames for the Techno and Fragmented Worlds. The other basins showed similar trends regarding the different storylines. 


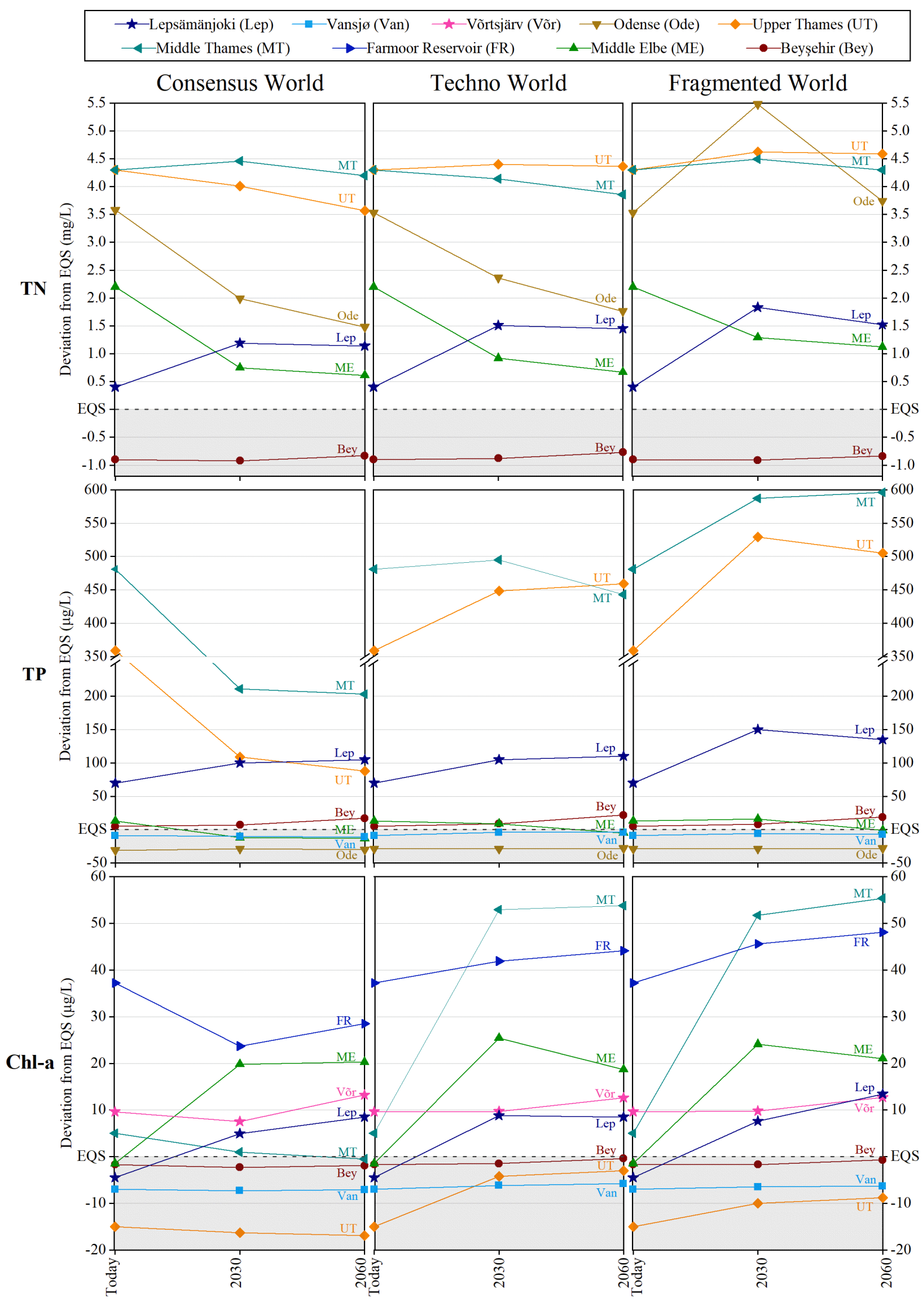

Figure 2: Modeled baseline and future concentrations of total nitrogen (TN), total phosphorus (TP) and chlorophyll-a (Chl-a), relative to the ecosystem type-specific threshold concentrations for good ecological status (EQS). The differences between the storylines are shown, highlighting a higher risk of failing the EQS for the Techno and Fragmented than for the Consensus World. Grey fields mark concentrations supporting the achievement 
Table 5: Overview of TN (total nitrogen), TP (total phosphorus) and chlorophyll-a concentrations for baseline and future scenarios of the different case studies, including threshold values of the environmental quality standards (EQS). Nutrient and chlorophyll-a concentrations meeting the EQS are marked in grey.

\begin{tabular}{|c|c|c|c|c|c|c|c|c|}
\hline \multirow{2}{*}{ Case study } & \multirow{2}{*}{ EQS } & \multirow{2}{*}{ Baseline $^{a}$} & \multicolumn{2}{|c|}{ Consensus World } & \multicolumn{2}{|c|}{ Techno World } & \multicolumn{2}{|c|}{ Fragmented World } \\
\hline & & & 2030 & 2060 & 2030 & 2060 & 2030 & 2060 \\
\hline \multicolumn{9}{|c|}{$\mathrm{TN}[\mathrm{mg} / \mathrm{L}]$} \\
\hline Lepsämänjoki & $1.6^{\mathrm{e}}$ & 2.0 & 2.8 & 2.7 & 3.1 & 3.1 & 3.4 & 3.1 \\
\hline Odense $^{\mathrm{d}}$ & $2.5^{\mathrm{e}}$ & $6.0 / 6.1^{\mathrm{d}}$ & 4.5 & 4.0 & 4.9 & 4.3 & 8.0 & 6.2 \\
\hline Upper Thames & $2.1^{\mathrm{e}}$ & 6.4 & 6.1 & 5.7 & 6.5 & 6.5 & 6.7 & 6.7 \\
\hline Middle Thames & $2.1^{\mathrm{e}}$ & 6.4 & 6.6 & 6.3 & 6.2 & 6.0 & 6.6 & 6.4 \\
\hline Middle Elbe $e^{c}$ & $2.1^{\mathrm{e}}$ & 4.3 & 2.9 & 2.7 & 3.0 & 2.8 & 3.4 & 3.2 \\
\hline Lake Beyşehir & $1.1^{\mathrm{e}}$ & 0.2 & 0.2 & 0.3 & 0.2 & 0.3 & 0.2 & 0.3 \\
\hline \multicolumn{9}{|c|}{$\overline{~ T P}[\mu \mathrm{g} / \mathrm{L}]$} \\
\hline Lepsämänjoki & $25^{\mathrm{e}}$ & 95 & 125 & 130 & 130 & 135 & 175 & 160 \\
\hline Lake Vansj $\varnothing^{b}$ & $27^{\mathrm{e}}$ & 12 & 10 & 9 & 13 & 13 & 16 & 16 \\
\hline Odense $^{\mathrm{d}}$ & $110^{\mathrm{e}}$ & $81 / 79^{\mathrm{d}}$ & 81 & 80 & 81 & 82 & 81 & 82 \\
\hline Upper Thames & $65^{\mathrm{f}}$ & 424 & 174 & 153 & 513 & 524 & 594 & 570 \\
\hline Middle Thames & $65^{\mathrm{f}}$ & 546 & 276 & 268 & 560 & 508 & 652 & 661 \\
\hline Middle Elbe ${ }^{c}$ & $90^{\mathrm{g}}$ & 103 & 78 & 78 & 99 & 85 & 106 & 90 \\
\hline Lake Beyşehir & $23^{\mathrm{e}}$ & 28 & 30 & 40 & 32 & 45 & 31 & 42 \\
\hline \multicolumn{9}{|c|}{ 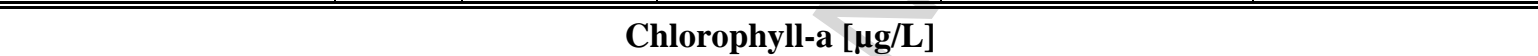 } \\
\hline Lepsämänjoki & $14.5^{\mathrm{h}}$ & 10.0 & 19.4 & 23.0 & 23.3 & 23.0 & 22.1 & 27.9 \\
\hline Lake Vansjø $\varnothing^{\mathrm{b}}$ & $10.5^{\mathrm{i}}$ & 3.5 & 3.2 & 3.4 & 4.0 & 4.2 & 4.3 & 4.7 \\
\hline Lake Võrtsjärv & $23.0^{\mathrm{k}}$ & 32.6 & 30.5 & 36.2 & 32.7 & 35.6 & 32.8 & 35.7 \\
\hline Upper Thames & $33.0^{\mathrm{g}}$ & 18.0 & 16.7 & 16.1 & 28.8 & 30.0 & 23.0 & 24.2 \\
\hline Middle Thames & $33.0^{\mathrm{g}}$ & 38.0 & 34.0 & 32.5 & 85.9 & 86.8 & 84.7 & 88.4 \\
\hline Farmoor Reservoir & $10.0^{\mathrm{k}}$ & 47.2 & 33.7 & 38.5 & 51.9 & 54.1 & 55.6 & 58.1 \\
\hline Middle Elbe $^{c}$ & $52.0^{\mathrm{g}}$ & 50.5 & 71.8 & 72.3 & 77.4 & 70.7 & 76.1 & 73.0 \\
\hline Lake Beyşehir & $5.1^{1}$ & 3.4 & 2.8 & 3.3 & 3.6 & 4.7 & 3.4 & 4.4 \\
\hline
\end{tabular}

${ }^{a}$ Baseline periods were chosen as follows: Beyşehir 2006-2015; Middle Elbe 2001-2010; Odense 2011-2020; Thames basin 2009-2012; Lake Võrtsjärv 2005-2014; Lepsämänjoki 2004-2013; Lake Vansjo 1983-2070 (an extended baseline was used: the observed baseline conditions of 1983-2014 were combined with generated conditions for 2015-2070).

${ }^{b}$ Modeling periods were chosen as 2020-2040 ('2030') and 2050-2070 ('2060').

${ }^{c}$ Modeling periods were chosen as 2020-2030 ('2030') and 2045-2055 ('2060').

${ }^{d}$ Future projections from Ferreira et al. (2016). Baselines: Consensus/ Techno and Fragmented World.

${ }^{e}$ Phillips et al. (2018); ${ }^{f}$ UK Technical Advisory Group (2013); ${ }^{g}$ Mischke et al. (2011); ${ }^{h}$ Stefanidis et al. (2018); ${ }^{i}$ Couture et al. (2018); ${ }^{k}$ Poikane (2009); ${ }^{l}$ Beklioğlu et al. (2014). 


\section{Discussion}

\section{Model uncertainties}

For the validation of PMs, the statistical fits of $\mathrm{R}^{2}$ were not satisfactory for about half of the model applications, whereas PBIAS values were not satisfactory for four of nineteen applications. Studies showing low $\mathrm{R}^{2}$ but satisfactory PBIAS indicate that concentrations were modeled adequately, whereas their timing was not appropriately reflected. In these cases in particular, exact predictions of future concentrations should be interpreted with caution. For the EM validation, the explained variances were all good or very good. In general, we consider the simulated trends in nutrient and chlorophyll-a sufficiently reliable. Furthermore, following Grimm (1994), statistical fits should not always be the main criterion in complex modeling procedures, as appropriate simulations are also indicated by good visual fits (Elliott and May, 2008). These were satisfactory in all model predictions (Ferreira et al., 2016). In addition, calibration and validation have been conducted at daily time steps in most of the studies, which generally leads to poorer performance in terms of goodness-of-fit criteria than at weekly, monthly or seasonal time steps (Table 4; Gassman et al., 2007). Apart from that, a model comparison should be undertaken with care since validation was performed on different temporal scales.

Performing multi-site and multi-variate simulations induces several sources of uncertainties for water quality modeling, especially stemming from data availability and the model structure. Data availability depends not only on monitoring programs in place but also on the analytical capabilities. In the case study of Lake Beyşehir, for instance, in-lake nutrient concentrations of soluble reactive phosphorus and ammonium were lower than the detection limit (Bucak et al., 2018). Furthermore, the spatio-temporal resolution of monitoring data is often limited due to insufficient monitoring stations and measuring frequencies. Model inputs and validation data thus only represent 'snapshots' of the complex conditions within the 
basins (Couture et al., 2018). Model structure is based on simplifying system complexities, and with increasing simplification the model-induced error rises due to an insufficient description of involved processes (Loucks and van Beek, 2017). By contrast, the more input data a model requires, the higher is the possible data-induced error, in particular if unavailable input data has to be estimated or substituted by constants. Many models actually work with static variable inputs, thus ignoring changes in environmental processes over the modeling period (e.g. gradual changes in land use; Couture et al., 2018).

Climate modeling always entails uncertainty due to scenario and model selection (Gettelman and Rood, 2016). IPSL generally predicted higher future changes in temperature and precipitation (see Table 2), and also the year-to-year variations were more pronounced in comparison to GFDL (Couture et al., 2018; Ferreira et al., 2016). These differences were reflected by around $11 \%$ variance in the water quality model outputs when using GFDL or IPSL. We have chosen to average the nutrient and chlorophyll-a concentrations per case study resulting from the different climate models to facilitate the synthesis sought in our study.

Another source of uncertainty is the chaining of models, where one model is feeding data into another and thus error magnification may occur (Fowler et. al., 2007). Model results that are biased or have an insufficient representation of short-time or small-scale variations cause imprecise predictions in the succeeding models (Kiesel et al., 2018). This occurred, for instance, in the Thames modeling, where the low temporal resolution of simulated flows did not adequately represent summer low flows, and, in consequence, future phosphorus concentrations were overestimated (Hutchins et al., 2018).

Model downscaling represents an additional source of uncertainty. In climate modeling, uncertainty depends on the method of transferring large scale variables into regional scale 
(Wootten et al., 2017). While the downscaling of the RCPs is based on objective procedures, the downscaling of SSPs and land use changes is based on assumptions regarding future socio-economic, political or technological developments in the respective basins, which cannot be exactly forecasted with today's knowledge. The scenario downscaling was based on expert judgement, therefore the different implementations by the case studies represent plausible futures, but assessing their uncertainties remains difficult (e.g. Cremona et al., 2017; Hutchins et al., 2018).

Our modeling procedures included many approaches to minimize uncertainties (e.g. averaging the predictions of both climate models, involving expert knowledge) and we assume that they represent the best practice of the current state-of-the-art. Optimizing the model application still needs a lot of work in terms of completing our conceptual understanding of natural processes. Given the stochastic nature of complex environmental systems and the probable effects from the various error and uncertainty sources, the results presented should generally be regarded as potential future scenario conditions. Achieving complete certainty in model simulations, however, will always remain an idealistic objective.

\section{Model simulations for nutrient and chlorophyll-a concentrations}

To discuss the driving forces determining the projected nutrient and chlorophyll-a concentrations, we start with outlining how changes in agriculture, urbanization and climate generally affect surface water quality. Against this background, we identify the main driving forces steering baseline and projected concentrations of TN, TP and chlorophyll-a in each case study. As a conclusion, we will outline the results in a European context. 


\section{Processes driving nutrient and chlorophyll-a concentrations in surface waters}

While the highest proportion of $\mathrm{TN}$ in the environment is soluble, TP tends to adhere to soil particles and consequently often occurs in particulate forms. This determines the dominant input pathways for the two nutrients. On agricultural land they mostly stem from fertilizer application, and TN is largely transported in soluble form via surface run-off, sub-surface flow and groundwater (Grizzetti et al., 2011; Viaroli et al., 2018), whereas particulate TP largely originates from erosion of topsoil and banks (Hong et al., 2012; Withers and Jarvie, 2008). Additionally, in some basins (e.g. Odense) there may be a substantial input via groundwater of dissolved phosphorus from natural sources. Land conversion from naturally vegetated to agricultural land, in particular, drives nutrient pollution in surface waters by reducing the nutrient retention capacity of soils, and by increasing nutrient surface run-off and erosion, often exacerbated by the installation of tile drainage (Weigelhofer et al., 2018).

Urbanization impacts include the amount and quality of WWTP effluents fed into the water bodies, depending on population size and treatment efficiency. Nutrient concentrations in effluents can be highly variable, as demonstrated in the Middle Elbe case study with effluents comprising ranges from 0.5 to $72.5 \mathrm{mg} / \mathrm{L} \mathrm{TN}$ and 0.1 to $10.4 \mathrm{mg} / \mathrm{L} \mathrm{TP}$, respectively (Mischke et al., 2016).

Climate change affects nutrient concentrations in surface waters due to changes in evaporation and precipitation, leading to alterations in generated run-off and involved nutrient inputs, as well as up- or down-concentration within the water body through hydrological alteration (e.g. changes in water volume or hydraulic residence time; Bucak et al., 2018; Molina-Navarro et al., 2018). In our study, the climate change effects were mainly influenced by the choice of the greenhouse gas emission trajectory for the scenarios, with RCP 8.5 
inducing higher changes in climate and subsequent response variables than RCP 4.5 (Ferreira et al., 2016).

Chlorophyll-a, representing phytoplankton biomass, is affected by a complex suite of factors. Nutrient availability (in particular bioavailable phosphorus) has a strong influence on phytoplankton growth. Light, water temperature and discharge are additionally relevant for phytoplankton growth in surface waters (Bussi et al., 2016; Sherman et al., 2016), explaining the inconsistent nutrient-chlorophyll-a relationships observed in some of our case studies. Discharge in particular influences chlorophyll-a due to the water residence patterns, providing time for nutrient uptake, metabolization and growth, and acts as a mediator for up- or downconcentration (Jeppesen et al., 2014).

\section{Main drivers of the TN projections in the case studies}

The baseline concentrations of TN mainly depended on the current land uses. Only Lake Beyşehir met the EQS due to its relatively undisturbed basin surrounded by natural parks. The other basins, in contrast, are highly impacted by agriculture and urbanization, as reflected by their elevated excess for baseline concentrations. In Middle Elbe, the low water availability also contributes to an up-concentration of nutrients within the river.

The future TN projections were mainly driven by the anticipated changes in agricultural and urban land use. Agricultural practices determined future TN in Lake Beyşehir, Odense and Lepsämänjoki. In the latter, deforestation towards agricultural land induced increasing nutrient loading and therefore rising concentrations in all storylines. This rise was more pronounced for the Techno and Fragmented World, which also included increased fertilization. In Odense, climate change also influenced future predictions due to flow changes altering the nutrient transport capacity. Rising precipitation led to the dilution of TN loadings 
in Middle Elbe, resulting in decreasing concentrations irrespective of the particular future scenario. In Thames, urban land use related to population dynamics was determined to be the main driver of change in $\mathrm{TN}$.

\section{Main drivers of the TP projections in the case studies}

Regarding TP, all water bodies exceeded the EQS under baseline conditions, except for Lake Vansjø and Odense. The basin of Lake Vansjø has the smallest share of agricultural land compared to the other case studies, and urban impacts (WWTP effluents) are low at baseline conditions. Further, water quality has vastly improved at Vansjø in the past decade, such that future deterioration does not exceed EQS. The agriculture in the Odense basin is subject to strict phosphorus regulations by the Danish government, constantly reducing the phosphorus surplus on Danish fields (Maguire et al., 2009). The high concentrations of the Thames were overestimated due to an underestimation of baseflow and subsequent up-concentration of TP.

Land use changes were mainly driving the future TP projections in four basins: Lepsämänjoki, Lake Vansjø, Middle Elbe and Thames. In Lepsämänjoki and Lake Vansjø, changes in agricultural land cover and related fertilizer application were the main drivers of TP. Lepsämänjoki showed rising concentrations for all scenarios, despite a reduction in fertilizer application for the Consensus World due to the increasing agricultural area. This river basin is an erosion-sensitive area with clayey soils, and any agricultural activity risks increasing phosphorus concentrations in surface waters by topsoil erosion (Ferreira et al., 2016; Rankinen et al., 2019). In Middle Elbe and Thames, urbanization was the main factor of TP rise due to the quantity and quality of WWTP effluents. TP concentrations in effluents were influenced by the change in population size, and in the case of Middle Elbe by change in the per capita phosphorus-export (due to altering meat consumption). Increases in diffuse TP loads were also important in the Thames. 
Climate change was mainly driving the TP changes in Lake Beyşehir and Odense. In Southern Europe, water levels are expected to decrease dramatically due to reduced precipitation (Bucak et al., 2017), causing an up-concentration of TP. In addition, rising water temperatures will induce enhanced nutrient remobilization from sediments and thus increased TP concentrations in surface waters (Bucak et al., 2018). In Odense, increasing precipitation was seen as the main driver of TP loads into the water bodies for the Techno and Fragmented World (organic phosphorus via surface run-off, soluble phosphate via groundwater inflow; Molina-Navarro et al., 2018). Thus, a discharge increase led to increases in TP loads, but since flow volume also increased, concentrations remained nearly constant. For the Consensus World, flow remained constant and so did the TP concentrations.

\section{Main drivers of the chlorophyll-a projections in the case studies}

The baseline concentrations of chlorophyll-a met the EQS in Lepsämänjoki, Lake Vansjø, and Lake Beyşehir due to their relatively undisturbed basins, as compared to Lake Võrtsjärv. Despite high nutrient availability, low chlorophyll-a concentrations were modeled in the Thames and Middle Elbe. In the Thames, this can be attributed to the short residence times and the shading effect by bankside vegetation (20\% coverage) leading to light limitation and further cooling of the already relatively low river water temperatures (Hutchins et al., 2018). Middle Elbe features a particularly relaxed chlorophyll-a EQS as this river type shows low area-specific runoff, and thus the response of phytoplankton to high total phosphorus concentrations is naturally suppressed (Mischke et al., 2011).

The main drivers for future predictions of chlorophyll-a concentrations differed between case studies, showing a strong response to either land use, climate change or both. Changes in agricultural and urban land use were mainly driving the chlorophyll-a concentrations in 
Middle Elbe, Thames and Lake Vansjø. In the Thames, changes can be attributed either to the shading effect by riparian vegetation for the Consensus World, which was assumed to increase to represent coverage of about $40 \%$ of the bankside along the stream, or to higher baseflow brought about by water transfers which reduce the residence time for the Techno and Fragmented Worlds. Higher chlorophyll-a concentrations were projected for the Techno and Fragmented than for the Consensus World, this largely being due to removal of bankside trees and higher TP concentrations (Hutchins et al., 2018). A strong influence of riparian shading which mitigates phytoplankton growth was predicted in the Thames for the Consensus World, where a $100 \%$ increase in shading was projected. In contrast, rising water temperatures and decreasing flows led to elevated chlorophyll-a concentrations for the Techno and Fragmented Worlds (Hutchins et al., 2018). In Lake Beyşehir and Lake Võrtsjärv, climate change was identified as the main driver for chlorophyll-a concentrations. Increasing air temperature, decreasing precipitation and an overuse of water resources in Lake Beyşehir led to rising water temperatures and, hence, increased phytoplankton productivity (Bucak et al., 2018). In Lake Võrtsjärv, increasing chlorophyll-a concentrations were attributed to lower tributary flows and higher temperature (Cremona et al., 2017). In the Farmoor Reservoir (Thames basin) and Lepsämänjoki, land use and climate change both influenced chlorophyll-a predictions due to higher TP availability and water temperature (Ferreira et al., 2016; Hutchins et al., 2018; Rankinen et al., 2019). Only for the Consensus World scenario of the Farmoor Reservoir was an improvement in water quality predicted. This was due to the inflow of water containing fewer nutrients.

Although discussion of our results focused on the long term mean concentrations of chlorophyll-a, we forecast higher inter-annual variations for most of the case studies (Ferreira et al., 2016). These variations are of particular relevance in water management, since algal blooms may impair ecosystem functioning and drinking water quality. In this regard, the 
contribution of cyanobacteria to the total phytoplankton biovolume was predicted to rise with higher temperatures and water residence times, indicating an increased risk of harmful algal blooms (Ferreira et al., 2016; Kosten et al., 2012; Richardson et al., 2018).

\section{Main drivers and their effects in a European context}

Our findings illustrate the broad spectrum of human-induced water quality impairment, covering various multi-stressor settings across basins with different climatic and biogeographical characteristics. While the basins located in the Continental and Atlantic regions were primarily affected by land use changes, climate change was the main driver in the Mediterranean/Anatolian one. The Boreal basins showed combined impacts of land use and climate change and clearly reflected the future trend of climate-induced intensified agricultural activities shifting northwards. Regarding this change in land use, diffuse agricultural pollution should be a primary target for future reduction (Jeppesen et al., 2009; Molina-Navarro et al., 2018). The efficiency of WWTP processes has already increased significantly in recent decades (Elosegi et al., 2019) and several modeling studies revealed that the potential of nutrient reductions due to further WWTP improvement is insufficient to meet the good ecological status in the future (e.g. Charlton et al., 2018).

All these outcomes chiefly resemble the findings of other studies within and outside Europe, which revealed a strong (but regionally specific) influence of climate and land use change on nutrient and chlorophyll-a concentrations in surface waters (e.g. Almeida et al., 2018; Kaushal et al., 2014; Molina-Navarro et al., 2014; Shrestha et al., 2017; Viaroli et al., 2018). This underlines the representative character of the basins covered by our study. Interestingly, the projected changes in nutrient and chlorophyll-a concentrations were more pronounced in rivers than in lakes, implying more severe climate and land use change-driven impacts to be 
expected for rivers. The effects of nutrient stress, however, may not always manifest in these ecosystems, as short residence times and riparian shading dampen the ecological implications.

\section{Comparison of storylines and their effects on future predictions}

The future predictions highlighted that the mitigation measures implemented for the Consensus World best supported the achievement of good ecological status. This scenario seems most favorable to minimize negative anthropogenic impacts on European surface waters. The lower nutrient and chlorophyll-a predictions indicate that the measures to reduce nutrient inputs and phytoplankton growth were effectively improving the ecological status of the water bodies. However, future predicted concentrations were not always lowest for the Consensus World. For instance, specific technical improvements for the Techno World made for the potential to enhance the water quality in some case studies (e.g. by improving WWTP or irrigation efficiency). For the Fragmented World, in some cases the specific climatic and socio-economic conditions implied the extensification of farming, including land abandonment, for which the consequences are favorable to the ecological status. Our study showed that unless sympathetic management is prioritized future water resources may become unsustainable,. In some cases, water transfers will become essential to meet human and ecological demands. When this is necessary, whilst beneficial to the receiving basins, the impacts in the donor basins are likely to be highly adverse.

\section{Conclusion}

Our summary of future predictions for nutrients and chlorophyll-a implies higher eutrophication risks under the storylines of Techno and Fragmented World, which represent scenarios that are less environmentally friendly than the Consensus World storyline. The mitigation measures proposed in Consensus World thus seem to represent minimum standards to abate eutrophication problems. However, if good ecological status continues to be a central 
objective in environmental management, even more stringent measures are required to guarantee its achievement in European water bodies in the future.

The three different storylines included in our study represent plausible future developments of the political, socio-economic and environmental contexts. However, given the complexity of the socio-ecological systems featuring saltatory developments and non-linear relations, any prediction of the future is always highly uncertain. Use of predictive modeling nevertheless presents an expedient opportunity to assess the consequences of our current actions and to project possible future conditions. This work is thus an important contribution to support the decision-making processes in a complex world. The future depends on what we do today - a reminder that it is up to us to shape the world in either a sustainable or untenable way.

\section{Acknowledgements}

This study was funded by the MARS project (Managing Aquatic ecosystems and water Resources under multiple Stress) funded under the $7^{\text {th }}$ EU Framework Programme, Theme 6 (Environment including Climate Change), Contract No.: 603378 (http://www.marsproject.eu).

We thank Jan Lemm (University of Duisburg-Essen) for his support in GIS and all contributors to the individual case studies that this synthesis is based on. 


\section{References}

Almeida C., Ramos T. B., Segurado P., Branco P., Neves R., Proença de Oliveira R. (2018). Water Quantity and Quality under Future Climate and Societal Scenarios: A Basin-Wide Approach Applied to the Sorraia River, Portugal. Water. doi: 10.3390/w10091186

Arnold J. G., Srinivasan R., Muttiah, R. S. Williams J. R. (1998). Large area hydrologic modeling and assessment part I: Model development. Journal of the American Water Resources Association. doi:10.1111/j.1752-1688.1998.tb05961.x

Beklioğlu M., Bucak T., Erdoğan Ş., Çakıroğlu A. İ., Trolle D., Andersen H. E., Thodsen H., Elliott J. A. (2014). Deliverable 5.2: Lake Beyşehir modelling: Adaptive strategies to mitigate the impacts of climate change on European freshwater ecosystems. Research report of the EU research project REFRESH. Middle East Technical University, Ankara, 30 pp.

Birk, S. (2019). Detecting and quantifying the impact of multiple stress on river ecosystems. In: S. Sabater, R. Ludwig \& A. Elosegi (Eds.), Multiple stress in river ecosystems. Status, impacts and prospects for the future (pp. 235-253). Amsterdam: Elsevier.

Bolker B. M., Brooks M. E., Clark C. J., Geange S. W., Poulsen J. R., Stevens M., White H. H., Jada-Simone S. (2009). Generalized linear mixed models: a practical guide for ecology and evolution. Trends in Ecology and Evolution. doi: 10.1016/j.tree.2008.10.008

Boorman D. B. (2003). LOIS in-stream water quality modelling. Part 1. Catchments and methods. Science of the Total Environment. doi: 10.1016/S0048-9697(03)00064-0

Bucak T., Trolle D., Andersen H. E., Thodsen H., Erdoğan Ş., Levi E. E., Filiz N., Jeppesen E., Beklioğlu M. (2017). Future water availability in the largest freshwater Mediterranean lake is at great risk as evidenced from simulations with the SWAT model. Science of the Total Environment. doi: 10.1016/j.scitotenv.2016.12.149

Bucak T., Trolle D., Tavşanoğlu Ü. N., Çakıroğlu A. İ., Özen A., Jeppesen E., Beklioğlu M. (2018). Modeling the effects of climatic and land use changes on phytoplankton and water quality of the largest Turkish freshwater lake: Lake Beyşehir. Science of the Total Environment. doi: 10.1016/j.scitotenv.2017.11.258

Bussi G., Whitehead P. G., Bowes M. J., Read D. S., Prudhomme C., Dadson S. J. (2016). Impacts of climate change, land-use change and phosphorus reduction on phytoplankton in the River Thames (UK). Science of the Total Environment. doi: 10.1016/j.scitotenv.2016.02.109

Carvalho L., McDonald C., de Hoyos C., Mischke U., Phillips G., Borics G., Poikane S., Skjelbred B., Lyche Solheim A., van Wichelen J., Cardoso A. C. (2013). Sustaining recreational quality of European lakes: minimizing the health risks from algal blooms through phosphorus control. Journal of Applied Ecology. doi: 10.1111/1365-2664.12059

Chapra S. C., Boehlert B., Fant C., Bierman V. J., Henderson J., Mills D., Mas D. M. L., Rennels L., Jantarasami L., Martinich J., Strzepek K. M., Pearl H. W. (2017). Climate change impacts on harmful algal blooms in U.S. Freshwaters: A Screening-Level Assessment. Environmental Science and Technology. doi: 10.1021/acs.est.7b01498

Charlton M. B., Bowes M. J., Hutchins M. G., Orr H. G., Soley R., Davison P. (2018). Mapping eutrophication risk from climate change: Future phosphorus concentrations in English rivers. Science of the Total Environment. doi: 10.1016/j.scitotenv.2017.07.218

Conley D. J., Carstensen J., Ærtebjerg G., Christensen P. B., Dalsgaard T., Hansen J. L. S., Josefson A. B. (2007). Long-term changes and impacts of hypoxia in Danish coastal waters. Ecological Applications. doi: 10.1890/05-0766.1 
Côté I. M., Darling E. S., Brown C. J. (2016). Interactions among ecosystem stressors and their importance in conservation. Proceedings of the Royal Society B Biological Sciences. doi: $10.1098 / \mathrm{rspb} .2015 .2592$

Couture R.-M., De Wit H. A., Tominaga K., Kiuru P., Markelov I. (2015). Oxygen dynamics in a boreal lake responds to long-term changes in climate, ice phenology, and DOC inputs. Journal of Geophysical Research: Biogeosciences. doi: 10.1002/2015JG003065

Couture R.-M., Moe S. J., Lin Y., Kaste Ø., Haande S., Lyche Solheim A. (2018). Simulating water quality and ecological status of Lake Vansjø, Norway, under land-use and climate change by linking process-oriented models with a Bayesian network. Science of the Total Environment. doi: 10.1016/j.scitotenv.2017.11.303

Cremona F., Vilbaste S., Couture R.-M., Nõges P., Nõges T. (2017). Is the future of large shallow lakes blue-green? Comparing the response of a catchment-lake model chain to climate predictions. Climatic Change. doi: 10.1007/s10584-016-1894-8

Cremona F., Tuvikene L., Haberman J., Nõges P., Nõges T. (2018). Factors controlling the three-decade long rise in cyanobacteria biomass in a eutrophic shallow lake. Science of the Total Environment. doi: 10.1016/j.scitotenv.2017.11.250

Dufresne J.-L., Foujols M.-A., Denvil S., Caubel A., Marti O., Aumont O., Balkanski Y., Bekki S., Bellenger H., Benshila R., Bony S., Bopp L., Braconnot P., Brockmann P., Cadule P., Cheruy F., Codron F., Cozic A., Cugnet D., de Noblet N., Duvel J.-P., Ethé C., Fairhead L., Fichefet T., Flavoni S., Friedlingstein P., Grandpeix J.-Y., Guez L., Guilyardi E., Hauglustaine D., Hourdin F., Idelkadi A., Ghattas J., Joussaume S., Kageyama M., Krinner G., Labetoulle S., Lahellec A., Lefebvre M.-P., Lefevre F., Levy C., Li Z. X., Lloyd J., Lott F., Madec G., Mancip M., Marchand M., Masson S., Meurdesoif Y., Mignot J., Musat I., Parouty S., Polcher J., Rio C., Schulz M., Swingedouw D., Szopa S., Talandier C., Terray P., Viovy N., Vuichard N. (2013). Climate change projections using the IPSL-CM5 Earth System Model: From CMIP3 to CMIP5. Climate Dynamics. doi: 10.1007/s00382-012-1636-1

Dunne J. P., John J. G., Adcroft A. J., Griffies S. M., Hallberg R. W., Shevliakova E., Stouffer R. J., Cooke W., Dunne K. A., Harrison M. J., Krasting J. P., Malyshev S. L., Milly P. C. D., Phillipps P. J., Sentman L. T., Samuels B. L., Spelman M. J., Winton M., Wittenberg A. T., Zadeh N. (2012). GFDL's ESM2 Global Coupled Climate-Carbon Earth System Models. Part I: Physical Formulation and Baseline Simulation Characteristics. Journal of Climate. doi: 10.1175/JCLI-D-11-00560.1

Elith J., Leathwick J. R., Hastie T. (2008). A working guide to boosted regression trees. Journal of Animal Ecology. doi: 10.1111/j.1365-2656.2008.01390.x

Elliott J. A., May L. (2008). The sensitivity of phytoplankton in Loch Leven (U.K.) to changes in nutrient load and water temperature. Freshwater Biology. doi: 10.1111/j.13652427.2007.01865.x

Elosegi, A., Sabater, S., Ludwig, R. (2019). An Introduction to the Geography of Multiple Stressors. In: S. Sabater, R. Ludwig \& A. Elosegi (Eds.), Multiple stress in river ecosystems. Status, impacts and prospects for the future (pp. 131-137). Amsterdam: Elsevier.

European Commission (2000). Directive 2000/60/EC of the European Parliament and of the Council of 23 October 2000 establishing a framework for community action in the field of water policy. Official Journal of the European Communities 43, 1-72.

European Environment Agency (2002). Europe's biodiversity - biogeographical regions and seas. EEA report No 1/2002. European Environment Agency, Copenhagen. 
European Environment Agency (2018). European waters - assessment of status and pressures. EEA report No 7/2018. European Environment Agency, Copenhagen, 88 pp. doi: $10.2800 / 303664$

Ferreira T., Panagopoulos Y., Bloomfield J., Couture R.-M., Omerod S., Stefanidis K., Mimikou M., Hanganu J., Constantinescu A., Beklioğlu M., Bucak T., Erdoğan Ş., Çakıroğlu A. İ., Çakmak E., Coppens J., Almeida C., Branco P., Neves R., Seguardo P., Molina-Navarro E., Lu S., Trolle D., Andersen H. E., Kramer L., Kujiper M., de Louw P., Kaandorp V., Meijers E., Penning E., Hendriks D., Mischke U., Mahnkopf J., Gericke A., Venohr M., Prudomme C., Hutchins M., Elliott A., Abesser C., Hitt O., Mansour M., Bowes M., Gieswein A., Schinegger R., Aschauer C., Schmutz S., Wright R. F., Lin Y., Kaste Ø., Guerrero J.-L., Christiansen A., Persson J., Mutinova P., Rankinen K., Liukko N., Hellsten S., Cremona F., Whitehead P. G., Bussi G., Gutiérrez-Cánovas C. (2016). Deliverable 4.1: Case study synthesis. Final report of the EU research project MARS. University of Lisboa, Lisbon, 626 pp.

Ferreira, M. T., Globevnik, L., Schinegger, R. (2019). Water Stressors in Europe: New Threats in the Old World. In: S. Sabater, A. Elosegi \& R. Ludwig (Eds), Multiple Stressors in River Ecosystems (pp. 131-137). Amsterdam: Elsevier.

Fowler H. J., Blenkinsop S., Tebaldi C. (2007). Linking climate change modelling to impacts studies: Recent advances in downscaling techniques for hydrological modelling. International Journal of Climatology. doi: 10.1002/joc.1556

Gassman P. W., Reyes M. R., Green C. H., Arnold J. G. (2007). The soil and water assessment tool: Historical development, applications, and future research directions. Transactions of the American Society of Agricultural and Biological Engineers, 50 (4), 12111250. ISSN 0001-2351

Gettelman A., Rood R. B. (2016). Demystifying Climate Models - A Users Guide to Earth System Models. Berlin, Heidelberg: Springer Nature.

Grafton R. Q., Williams J., Perry C. J., Molle F., Ringler C., Steduto P., Udall B., Wheeler S. A., Wang Y., Garrick D., Allen R. G. (2018). The paradox of irrigation efficiency. Science. doi: $10.1126 /$ science.aat9314

Grimm V. (1994). Mathematical models and understanding in ecology. Ecological Modelling. doi: 10.1016/0304-3800(94)90056-6

GrizettI, B., Bouraoui, F., Billen, G., van Grinsven, H., Cardoso, A. C, Thieu, V., Garnier, J., Curtis, C., Howarth, R., Johnes, P. (2011). Nitrogen as a threat to European water quality. In: M. A. Sutton, C. M. Howard, J. W. Erisman, G. Billen, A. Bleeker, P. Grennfelt, H. van Grinsven \& B. Grizzetti (Eds.), The European Nitrogen Assessment (pp. 379-404). Cambridge: Cambridge University Press.

Hering D., Carvalho L., Argillier C., Beklioglu M., Borja A., Cardoso A. C., Duel H., Ferreira T., Globevnik L., Hanganu J., Hellsten S., Jeppesen E., Kodes V., Lyche Solheim A., Nöges T., Ormerod S., Panagopoulos Y., Schmutz S., Venohr M. and Birk S. (2015). Managing aquatic ecosystems and water resources under multiple stress - An introduction to the MARS project. Science of the Total Environment. doi: 10.1016/j.scitotenv.2014.06.106

Hipsey M. R., Bruce L. C., Boon C., Busch B., Carey C. C., Hamilton D. P., Hanson P. C., Read J. S., de Sousa E., Weber M., Winslow L. A. (2017). A General Lake Model (GLM 2.4) for linking with high-frequency sensor data from the Global Lake Ecological Observatory Network (GLEON). Geoscientific Model Development Discussion. doi: 10.5194/gmd-2017257 
Hong B., Swaney D. P., Mörth C.-M., Smedberg E., Eriksson Hägg, H., Humborg C., Howarth R. W., Bouraoui F. (2012). Evaluating regional variation of net anthropogenic nitrogen and phosphorus inputs (NANI/NAPI), major drivers, nutrient retention pattern and management implications in the multinational areas of Baltic Sea basin. Ecological Modelling. doi: 10.1016/j.ecolmodel.2011.12.002

Hutchins M. G., Williams R. J., Prudhomme C., Bowes M. J., Brown H. E., Waylett A. J., Loewenthal M. (2016). Projections of future deterioration in UK river quality are hampered by climatic uncertainty under extreme conditions. Hydrological Sciences Journal. doi: 10.1080/02626667.2016.1177186

Hutchins M. G., Abesser C., Prudhomme C., Elliott J. A., Bloomfield J. P., Mansour M. M., Hitt O. E. (2018). Combined impacts of future land-use and climate stressors on water resources and quality in groundwater and surface waterbodies of the upper Thames river basin, UK. Science of the Total Environment. doi: 10.1016/j.scitotenv.2018.03.052

Jackson R. B., Jobbagy E. G., Avissar R., Roy S. B., Barrett D. J., Cook C. W., Farley K. A., le Maitre D. C., McCarl B. A., Murray B. C. (2005). Trading Water for Carbon with Biological Carbon Sequestration. Science. doi: 10.1126/science.1119282

Janse J. H. (2005). Model studies on the eutrophication of shallow lakes and ditches. Doctoral Thesis, Wageningen University, Wageningen, 198 pp.

Jeppesen E., Kronvang B., Meerhoff M., Søndergaard M., Hansen K. M., Andersen H. E. Lauridsen T. L., Liboriussen L., Beklioglu M., Özen A., Olesen J. E. (2009). Climate Change Effects on Runoff, Catchment Phosphorus Loading and Lake Ecological State, and Potential Adaptations. Journal of Environmental Quality. doi: 10.2134/jeq2008.0113

Jeppesen E., Meerhoff M., Davidson T. A., Trolle D., Søndergaard M., Lauridsen T. L., Beklioglu M., Brucet S., Volta P., Gonzalez-Bergonzoni I., Nielsen A. (2014). Climate change impacts on lakes: An integrated ecological perspective based on a multi-faceted approach, with special focus on shallow lakes. Journal of Limnology. doi: 10.4081/jlimnol.2014.844

Kaushal S. S., Mayer P. M., Vidon P. G., Smith R. M., Pennino M. J., Newcomer T. A., Duan S., Welty C., Belt K. T. (2014). Land Use and Climate Variability Amplify Carbon, Nutrient, and Contaminant Pulses: A Review with Management Implications. Journal of the American Water Resources Association. doi: 10.1111/jawr.12204

Kiesel, J., Guse, B., Bormann, H. (2018). Projecting the Consequences of Climate Change on River Ecosystems. In: S. Sabater, R. Ludwig \& A. Elosegi (Eds.), Multiple stress in river ecosystems. Status, impacts and prospects for the future (pp. 281-301). Amsterdam: Elsevier.

Kosten S., Huszar V. L., Bécares E., Costa L. S., Donk E., Hansson L. A., Jeppesen E., Kruk C., Lacerot G., Mazzeo N., de Meester L., Moss B., Lürling M., Nõges T., Romo S., Scheffer M. (2012). Warmer climates boost cyanobacterial dominance in shallow lakes. Global Change Biology. doi: 10.1111/j.1365-2486.2011.02488.x

Levi E. E., Bezirci G., Çakıroğlu A. İ., Turner S., Bennion H., Kernan M., Jeppesen E., Beklioğlu M. (2016). Multi-proxy palaeoecological responses to water-level fluctuations in three shallow Turkish lakes. Palaeogeography, Palaeoclimatology, Palaeoecology. doi: 10.1016/j.palaeo.2016.02.052

Lindenschmidt K.-E. (2006). River water quality modelling for river basin and water resources management with a focus on the Saale River, Germany. Habilitation Thesis, Brandenburgische Technische Universität Cottbus, Cottbus, 145 pp. 
Loucks, D. P., van Beek, E. (2017). Water Resource Systems Planning and Management: An Introduction to Methods, Models, and Applications. Basle: Springer International Publishing.

Maguire, R.O., Rubaek, G.H., Haggard, B.E., Foy, B.H. (2009). Critical Evaluation of the Implementation of Mitigation Options for Phosphorus from Field to Catchment Scales. Journal of Environmental Quality. doi: 10.2134/jeq2007.0659

Mischke, U., Venohr, M., Behrendt, H. (2011). Using Phytoplankton to Assess the Trophic Status of German Rivers. International Review of Hydrobiology 96, 578-598. doi: 10.1002/iroh.201111304

Mischke U., Mahnkopf J., Gericke A., Venohr M. (2016). Simulation of the effect of riparian shading and nutrient reduction measures on phytoplankton in Middle Elbe basin (Germany). Basin report for the Leibniz-Institute for Freshwaters and Inland Fisheries, 35 pp.

Mischke U., Gericke A., Venohr M. (2018). PhytoBasinRisk - A new model to estimate the risk of phytoplankton blooms along large river systems. Model description. Leibniz Institute of Freshwater Ecology and Inland Fisheries, Berlin: http://www.moneris.igbberlin.de/index.php/PhytoBasinRisk.html

Moe S. J., Haande S., Couture R.-M. (2016). Climate change, cyanobacteria blooms and ecological status of lakes: A Bayesian network approach. Ecological Modelling. doi: 10.1016/j.ecolmodel.2016.07.004

Molina-Navarro E., Trolle D., Martínez-Pérez S., Sastre-Merlín A., Jeppesen E. (2014). Hydrological and water quality impact assessment of a Mediterranean limno-reservoir under climate change and land use management scenarios. Journal of Hydrology. doi: 10.1016/j.jhydrol.2013.11.053

Molina-Navarro E., Andersen H. E., Nielsen A., Thodsen H., Trolle D. (2018). Quantifying the combined effects of land use and climate changes on stream flow and nutrient loads: A modelling approach in the Odense Fjord catchment (Denmark). Science of the Total Environment. doi: 10.1016/j.scitotenv.2017.11.251

Moriasi D. N., Gitau M. W., Pai N., Daggupati P. (2015). Hydrologic and water quality models: Performance measures and evaluation criteria. Transactions of the American Society of Agricultural and Biological Engineers. doi: 10.13031/trans.58.10715

Nõges T., Anneville O., Guillard J., Haberman J., Järvalt A., Manca M., Morabito G., Rogora M., Thackeray S. J., Volta P., Winfield I. J., Nõges P. (2018). Fisheries impacts on lake ecosystem structure in the context of a changing climate and trophic state. Journal of Limnology. doi: 10.4081/jlimnol.2017.1640

O’Neill B. C., Kriegler E., Ebi K. L., Kemp-Benedict E., Riahi K., Rothman D. S., van Ruijven B. J., van Vuuren D. P., Birkmann J., Kok K., Levy M., Solecki W. (2017). The roads ahead: Narratives for shared socioeconomic pathways describing world futures in the 21st century. Global Environmental Change. doi: 10.1016/j.gloenvcha.2015.01.004

Ormerod S. J., Dobson M., Hildrew A. G., Townsend C. R. (2010). Multiple stressors in freshwater ecosystems. Freshwater Biology. doi: 10.1111/j.1365-2427.2009.02395.x

Phillips, G., Kelly, M., Teixeira, H., Salas, F., Free, G., Leujak, W., Solheim, A. L., Várbíró, G., Poikane, S. (2018). Best practice for establishing nutrient concentrations to support good ecological status. Technical report EUR 29329 EN. Publications Office of the European Union, Luxembourg, 142 pp. doi: 10.2760/84425

Poikane S. (Ed.) (2009). Water Framework Directive Intercalibration Technical Report, Part 2: Lakes. Technical report EUR 23838 EN/2. Institute for Environment and Sustainability, Ispra, 177 pp. doi: 10.2788/23415 
Rankinen, K., Cano Bernal, J. E., Holmberg, M., Vuorio, K., Granlund, K. (2019). Identifying multiple stressors that influence eutrophication in a Finnish agricultural river. Science of the Total Environment 658, 1278-1292. doi: 10.1016/j.scitotenv.2018.12.294

Reynolds C. S., Irish A. E., Elliott J. A. (2001). The ecological basis for simulating phytoplankton responses to environmental change (PROTECH). Ecological Modelling. doi: 10.1016/S0304-3800(01)00330-1

Richardson J., Miller C., Maberly S. C., Taylor P., Globevnik L., Hunter P., Jeppesen E., Mischke U., Moe J., Pasztaleniec A., Søndergaard M., Carvalho L. (2018). Effects of multiple stressors on cyanobacteria abundance varies with lake type. Global Change Biology. doi: $10.1111 / \mathrm{gcb} .14396$

Sabater, S., Ludwig, R., Elosegi, A. (2019). Defining multiple stressor implications. In: S. Sabater, R. Ludwig \& A. Elosegi (Eds.), Multiple Stress in River Ecosystems. Status, Impacts and Prospects for the Future (pp. 1-22). Oxford: Academic Press.

Sala O. E., Chapin F. S., Armesto J. J., Berlow E., Bloomfield J., Dirzo R., Huber-Sanwald E., Huenneke L. F., Jackson R. B., Kinzig A., Leemans R., Lodge D. M., Mooney H. A., Oesterheld M., Poff N. L., Sykes M. T., Walker B. H., Walker M., Wall D. H. (2000). Global biodiversity scenarios for the year 2100. Science. doi: 10.1126/science.287.5459.1770

Saloranta T. M., Andersen T. (2007). MyLake-A multi-year lake simulation model code suitable for uncertainty and sensitivity analysis simulations. Ecological Modelling. doi: 10.1016/j.ecolmodel.2007.03.018

Sanchez F. M., Duel H., Alejos Sampedro A., Rankinen K., Holmberg M., Prudhomme C., Birk S. (2015). Deliverable 2.1: Four manuscripts on the multiple stressor framework, Part 4: Report on the MARS scenarios of future changes in drivers and pressures with respect to Europe's water resources. Research report of the EU research project MARS. Stichting Deltares, Delft, 288 pp.

Segurado P., Almeida C., Neves R., Ferreira M. T., Branco P. (2018). Understanding multiple stressors in a Mediterranean basin: Combined effects of land use, water scarcity and nutrient enrichment. Science of the Total Environment. doi: 10.1016/j.scitotenv.2017.12.201

Sherman E., Moore J. K., Primeau F., Tanouye D. (2016). Temperature influence on phytoplankton community growth rates. Global Biogeochemical Cycles. doi: $10.1002 / 2015 \mathrm{~GB} 005272$

Shrestha M. K., Recknagel F., Frizenschaf J., Meyer W. (2017). Future climate and land uses effects on flow and nutrient loads of a Mediterranean catchment in South Australia. Science of the Total Environment. doi: 10.1016/j.scitotenv.2017.02.197

Skarbøvik E., Bechmann M. (2010). Some Characteristics of the Vansjø-Hobøl (Morsa) Catchment. Bioforsk report Volume 5, No. 128. Norwegian Institute for Agricultural and Environmental Research, Ås, 44 pp.

Smeets E., Weterings R. (1999). Environmental indicators: Typology and overview. Technical report No. 25 of the European Environment Agency. TNO Centre for Strategy, Technology and Policy, Amsterdam, 19 pp.

Stefanidis K., Panagopoulos Y., Mimikou M., Spears B., Chapman D., Ives S., Richardson J., Carvalho L., Birk S., Rankinen K., Järvinen M. (2018). Deliverable 6.2: Synthesis report describing potential risks to status and services in relation to future scenarios of land-use change in combination with extreme climate events and possible mitigation options. Part 1: Assessing the effects of multiple stressors across scales and models for assessing multiple 
stressor mitigation options. Report of the EU research project MARS. National Technical University of Athens, Athens, $52 \mathrm{pp}$.

Thodsen H., Andersen H. E., Blicher-Mathiesen G., Trolle D. (2015). The combined effects of fertilizer reduction on high risk areas and increased fertilization on low risk areas, investigated using the SWAT model for a Danish catchment. Acta Agriculturae Scandinavica, Section B — Soil \& Plant Science. doi: 10.1080/09064710.2015.1010564

Thomson A. M., Calvin K. V., Smith S. J., Kyle G. P., Volke A., Patel P., Delgado-Arias S., Bond-Lamberty B., Wise M. A., Clarke L. E., Edmonds J. A. (2011). RCP4.5: A pathway for stabilization of radiative forcing by 2100. Climatic Change. doi: 10.1007/s 10584-011-0151-4

Tsakiris G., Alexakis D. (2012). Water quality models: An overview. European Water 37, 3346.

UK Technical Advisory Group (2013). Updated recommendations on phosphorus standards for rivers. River Basin Management (2015-2012). Final report. Environment Agency, Bristol, $12 \mathrm{pp}$.

van Vuuren D. P., Edmonds J., Kainuma M., Riahi K., Thomson A., Hibbard K., Hurtt G. C., Kram T., Krey V., Lamarque J.-F., Masui T., Meinshausen M., Nakicenovic N., Smith S. J., Rose S. K. (2011). The representative concentration pathways: An overview. Climatic Change. doi: 10.1007/s10584-011-0148-z

Venohr M., Hirt U., Hofmann J., Opitz D., Gericke A., Wetzig A., Natho S., Neumann F., Hürdler J., Matranga M., Mahnkopf J., Gadegast M., Behrendt H. (2011). Modelling of nutrient emissions in river systems - MONERIS - methods and background. International Review of Hydrobiology. doi: 10.1002/iroh.201111331

Viaroli P., Soana E., Pecora S., Laini A., Naldi M., Fano E. A., Nizzoli D. (2018). Space and time variations of watershed $\mathrm{N}$ and $\mathrm{P}$ budgets and their relationships with reactive $\mathrm{N}$ and $\mathrm{P}$ loadings in a heavily impacted river basin (Po river, Northern Italy). Science of the Total Environment. doi: 10.1016/j.scitotenv.2018.05.233

Weigelhofer, G., Hein, T., Bondar-Kunze, E. (2018). Chapter 10: Phosphorus and Nitrogen Dynamics in Riverine Systems: Human Impacts and Management Options. In: S. Schmutz \& J. Sendzimir (Eds.), Riverine Ecosystem Management - Science for Governing Towards a Sustainable Future (187-201). Basle: Springer International Publishing.

Whitehead P. G., Wilson E. J, Butterfield, D (1998). A semi-distributed Integrated Nitrogen model for multiple source assessment in Catchments (INCA): Part I - Model structure and process equations. Science of the Total Environment. doi: 10.1016/S0048-9697(98)00037-0

Withers P. J. A., Jarvie H. P. (2008). Delivery and cycling of phosphorus in rivers: a review. Science of the Total Environment. doi: 10.1016/j.scitotenv.2008.08.002

Wootten A., Terando A., Reich B. J., Boyles R. P., Semazzi F. (2017). Characterizing Sources of Uncertainty from Global Climate Models and Downscaling Techniques. Journal of Applied Meteorology and Climatology. doi: 10.1175/JAMC-D-17-0087.1

WWF (2016). Living Planet Report 2016. Risk and resilience in a new era. WWF International, Gland, Switzerland, $145 \mathrm{pp}$. 
Graphical Abstract
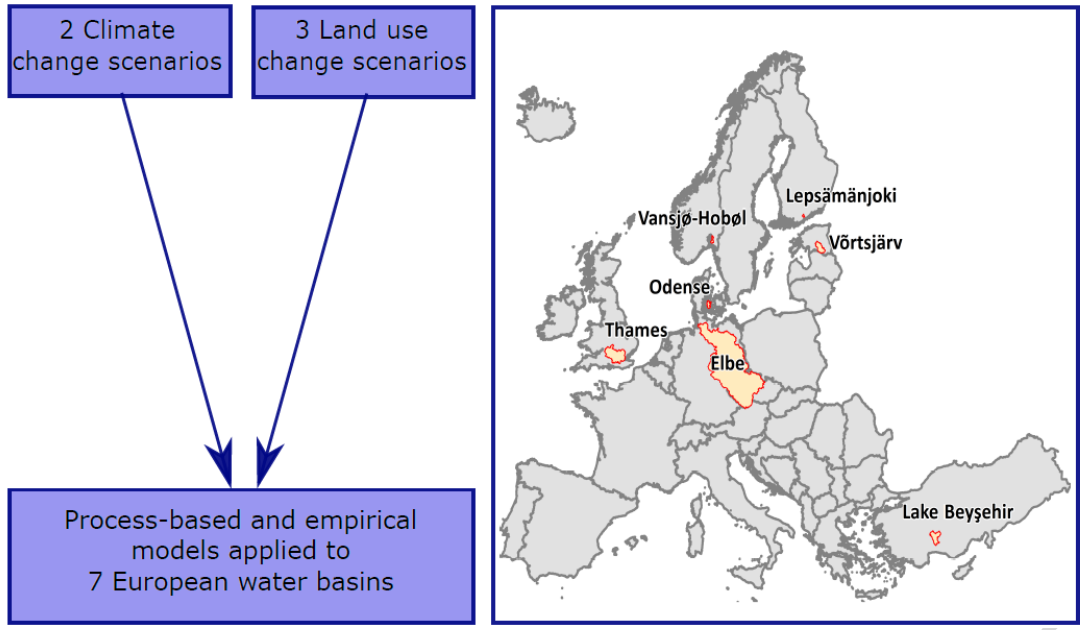

Future scenarios - 2060

\begin{tabular}{|c|c|c|}
\hline Consensus & Techno & Fragmented \\
World & World
\end{tabular}

World

World World

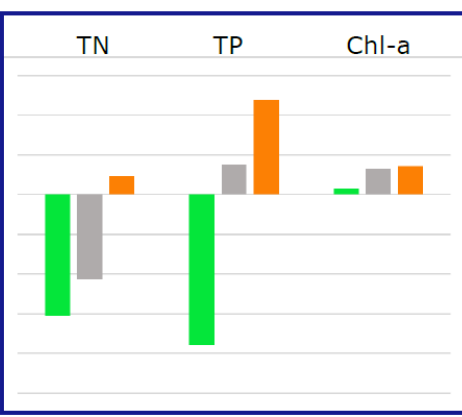




\section{Highlights}

- We synthesized studies modeling multiple stressor impacts on future water quality.

- Assessment was based on scenarios including socio-economic and climate change.

- Climate and land use change both drive the future water quality.

- Targeted measures are needed to attain good water quality in the future. 